Hydrol. Earth Syst. Sci. Discuss., https://doi.org/10.5194/hess-2018-380

Manuscript under review for journal Hydrol. Earth Syst. Sci.

Discussion started: 12 December 2018

(c) Author(s) 2018. CC BY 4.0 License.

COPULA AND ARMA BASED STUDY OF CONTROLLED OUTFLOW AT FARAKKA BARRAGE

Uttam Singh; Venkappayya R. Desai; Pramod K. Sharma; and Chandra S.P. Ojha

Email: uttamsingh426@gmail.com; venkapd@civil.iitkgp.ernet.in; drpksharma07@gmail.com; cspojha@gmail.com 


\section{COPULA AND ARMA BASED STUDY OF CONTROLLED OUTFLOW AT FARAKKA} BARRAGE

Uttam Singh ${ }^{1}$; Venkappayya R. Desai ${ }^{2}$; Pramod K. Sharma ${ }^{3}$; and Chandra S.P. Ojha ${ }^{4}$

${ }^{1,3,4}$ Department of Civil Engineering, Indian Institute of Technology Roorkee-247667

${ }^{2}$ Department of Civil Engineering, Indian Institute of Technology Kharagpur-721302

\section{Abstract}

In this study, 25 years mean monthly out flow discharge data of Farakka barrage was used (i.e., from 1949 to 1968). Farakka barrage is located between on Ganga River. Spatial and temporal variation in flow rate for any particular area is very common due to various meteorological and other factors existing in nature. But large variations in these factors cause extreme events (e. g., floods and droughts).Monthly outflow discharge for a particular critical month are predicted using statistical models (ARMA Model and Copula Model). Different Copulas (i.e., Normal, t, Frank, Clayton, Gumbel-Hoggard, Ali-Mikhail-Haq) are used for this purpose and the copula model is selected based on distribution functions (Normal distribution, Lognormal distribution, Extreme value type-1 distribution, Generalized Extreme value type, Gamma distribution, Weibull distribution, Exponential distribution). The distribution is selected based on the Mean square error (MSE), Akaike Information Criterion (AIC), and Bayesian Information Criterion (BIC). The model parameters were computed using the Maximum Likelihood (ML) estimation method.

Key words: Farakka barrage; ARMA, Copulas, Simulation; Discharge. 


\section{Introduction}

An accurate flood-frequency analysis is critical for the design of many civil infrastructures such as drainage system and flood proof walls. Copula word is taken from Latin language and the meaning of copula is link and the concept of copula was introduced in mathematical and statistical manner by Sklar (1959) in a theorem that describes a copula as a function. Afterwards, many researchers such as Genest and MacKay (1986), Genest and Rivest (1993) and Nelsen (1999), Favre et al. (2004), Genest and Favre (2007) and Salvadori and De Michele (2007) used in hydrology applications. Crucial steps for copulas modeling are driving the bivariate distribution of peak flow and volume, volume and duration, peak flow and duration (Zhang and Singh, 2006). Archimedean copulas (Clayton, Frank, Gumbel-Hoggard, Ali-Mikhail-Haq, Indpendance and Joe) can be used for bivariate modeling peak flow and volume, volume and duration, peak flow and duration.

Dependence structure of data set is captured by copulas, thus they are used for describing the dependence of o extreme output values and also useful for depandence non parametric measurement. Statistical dependence among three random variables two copulas are used for modeling. The Archimedean copulas are prepared by association measurement of Kendall's tau (Osorio et al. 2009). The probability density function for the two-dimensional random variable representing volume and time is given in graphic form. The graphs both represents Clayton copula and Gumbel-Hougaard functions. The Gumbel-Hougaard copula was best suited for this study because it shows lower value in selection criterion function. Gumbel-Hougaard copula shows better matching of empirical and theoretical distribution function. The results obtained in the study, risk values at extreme analyzed values of controlled discharge and flood control capacity are not monotonic. It represents that simulations were completed for sets of only 10000 cycle elements and only 10000 cycles (Twaróg, 2016). Peak flow and hydrograph volume both 
can be jointly studied by bivariate approach (e.g., Goel et al. 1998; Yue et al. 1999; Favre et al. 2004; Shiau et al. 2007). The selection of the, different criterion should be consider among the candidate copula (Chowdhary et al. 2011; Requena et al. 2013). The first criterion is the goodness-of-fit test which relates the ability of copula to characterize the data (Genest et al. 2009), The second criterion is estimation of kendall's tau return period estimation by copula. It relates the adequacy of copula, for a large copula value $t \in[0,1]$, which is based on the Kendall's function $\mathrm{K}_{C}(\mathrm{t})=\mathrm{P}\left[\mathrm{C}_{\Theta}\left(\mathrm{u}_{1}, \mathrm{u}_{2}\right) \leq \mathrm{t}\right]$ (Genest and Rivest,1993). The third criterion is the estimation of Akaike Information Criterion (AIC) (e.g., Zhang and Singh, 2006). A copula-based model and a distributed hydro-meteorological model and a copula-based model can be studied by combining extension of observed flood series (Requena, et al. 2015). Significant number of researchers found in their research that Gumbel-Hougaard copula as the most suitable choice to model the dependence structure relating to the peak flow discharge and the flood volume (De Michele et al., 2005; Zhang and Singh, 2007, Karmakar and Simonovic, 2009 and Li et al., 2013). A copula-based approach was used to derive a bivariate distribution function of two constituent flood variables, with regard to a real-world case study. It was found to provide an effective and straightforward strategy for inferring probability functions from multivariate sample data. Powerful tests developed inside copula framework allowed to investigate the empirical dependence structure in an accurate manner, especially with respect to the evaluation of tail dependencies (Balistrocchi, 2017). The dependence of copula model between intensity and rain fall duration, both properties of marginal distribution and dependence between intensity and storm duration were preserved. The Joint cumulative distribution functions represents dependence between independent variables of their marginal distribution of copula (Joe, 1997 and Nelsen, 2006). Gaussian copula was used for generation of 1020 synthetic data sets. Among 
the data sets, 21 data sets lies beyond the range of acceptance so these data sets were omitted. Of course it is not possible to cover all input-output cases in trained models the extrapolation limit are required (Hooshyaripor et al. 2014). Best copula model can be selected by coarse grid model selection with supposedly known marginal parameters in which 15 families of copulas were divided into 4 categories and selection with uncertain marginal parameters (Parent et al. 2013). Copula is a tool for modeling multivariate distribution in which input is the marginal distribution. Multivariate distribution function couples to the corresponding marginal distribution. (Poulin et al., 2007; Salvadori et al., 2007). The monsoon rainfall of Assam, Meghalaya and Nagaland, Manipur, Mizoram, Tripura, Gumbel-Hoggard copula model was well simulates for rain fall estimation (Ghosh, 2010). Marginal distributions and correlations values are used to simulate the Gaussian model. They were taken four case studies to demonstrate its usefulness in the reference of determination of field significance analysis, analysis of regional risk, frequency analysis and design of hydrograph derivation by QdF models. (Renard et al. 2007). Copulas are very good tool to model multivariate data and they are very useful in financial economics as well and in the analysis of multivariate survival data. Dependent variables are very useful Monte Carlo simulations for copula model. It estimates the structural dependence of the data set and describe accurately for dependence of extreme out come. (Muhaisen, et al. 2006). Multivariate probability distributions with arbitrary marginal can be constructed in a flexible manner with the introduction of copulas (Wang et al. 2001). Major issue of a copula is the compatibility with dimensions though they were successfully tested and applied on several hydrological problems. (Kao and Govindaraju, 2008). Application of copula in the engineering problem need moderate and minimal computational effort and accuracy of the 
rainfall dependence in sub-basins decreases up to $18 \%$. To predict decrease runoff error spatial rainfall dependence could be recommended for copula modeling (Razmkhah, 2016).

The aim of this paper is to generate the out flow discharge data at Farakka barrage using Copulas. In this study, Normal Copula, T- Copula, Frank Copula, Clayton Copula, GumbelHoggard (GH) copula, Ali-Mikhail-Haq(AMH) copula are used and best copula is selected for generation of discharge data based on copula parameters, Mean square error(MSE), Akaike Information criterion(AIC), Bayesian Information criterion (BIC).

ARIMA model was developed to forecast monthly inflow discharge in a reservoir system (Mohan et al., 1955 ). Criteria for model selection are residual variance(Katz et al. 1981), Akaike information criteria ( Akaike 1974) and Posterior probability criteria (Kashyap 1977).

\section{Copulas used for study}

Copulas are alternative methods for dealing with multivariate extremes, and these are very popular in recent times. Consider a moment pair of random variables $U$ and $V$, with their distribution functions $\mathrm{F}(\mathrm{u})=\mathrm{P}[\mathrm{U} \leq \mathrm{u}]$ and $\mathrm{G}(\mathrm{v})=\mathrm{P}[\mathrm{V} \leq \mathrm{v}]$, respectively, and a joint distribution function $H(\mathrm{u}, \mathrm{v})=\mathrm{P}[\mathrm{U} \leq \mathrm{u}, \mathrm{V} \leq \mathrm{v}]$. Each pairs having of real numbers $(\mathrm{u}, \mathrm{v})$, associated three numbers: $\mathrm{F}(\mathrm{u}), \mathrm{G}(\mathrm{v})$, and $\mathrm{H}(\mathrm{u}, \mathrm{v})$ and each numbers are lie in the interval $[0,1]$. In other words, each pair of real numbers i.e. $(\mathrm{u}, \mathrm{v})$ leads to a point $\{\mathrm{F}(\mathrm{u}), \mathrm{G}(\mathrm{v})\}$ in the unit square $[0,1] \times[0,1]$, and this ordered pair in turn corresponds to a number $\mathrm{H}(\mathrm{u}, \mathrm{v})$ in $[0,1]$. We will show that this correspondence, those values are assign in the joint distribution function to each values of ordered pair in the individual distribution functions. Such functions are named as copulas.

A copula is used as a tool in modeling multivariate distribution in which marginal distributions are input data and neglect restrictions mentioned in pervious text. Copula means couples or joins 
multivariate distribution functions to their corresponding distribution functions of their corresponding marginal distribution functions (Poulin et al., 2007; Salvadori et al., 2007).

\begin{tabular}{|c|c|c|c|c|}
\hline $\begin{array}{l}\text { S. } \\
\text { No. }\end{array}$ & Copula & Equation & $\begin{array}{l}\text { Generating } \\
\text { function }\end{array}$ & $\begin{array}{l}\text { Relation with } \\
\tau\end{array}$ \\
\hline 1 & Normal & $\begin{array}{l}\mathrm{C}\left(\mathrm{x}_{1}, \mathrm{x}_{2}, \ldots \ldots \ldots, \mathrm{x}_{\mathrm{p}}\right)=\mathrm{P}\left[\mathrm{U}_{1} \leq \mathrm{F}^{-1}{ }_{1}\left(\mathrm{x}_{1}\right), \mathrm{U}_{2}\right. \\
\left.\leq \mathrm{F}^{-1}{ }_{2}\left(\mathrm{x}_{2}\right), \ldots \ldots, \mathrm{U}_{\mathrm{p}} \leq \mathrm{F}^{-1}{ }_{\mathrm{p}}\left(\mathrm{x}_{\mathrm{p}}\right)\right]\end{array}$ & & \\
\hline 2 & $\mathrm{~T}$ & $\begin{array}{l}\mathrm{C}\left(\mathrm{x}_{1}, .\right. \\
\left.\mathrm{F}_{\mathrm{d}}^{-1}\left(\mathrm{x}_{\mathrm{d}}\right)\right)\end{array}$ & & \\
\hline 3 & Frank & $\mathrm{C}_{\Theta}(\mathrm{x}, \mathrm{y})=\frac{1}{\theta} \ln \left[1+\frac{[\exp (\theta x)-1][\exp (\theta y)-1]}{\exp (\theta)-1}\right.$ & $\begin{array}{l}\Phi(\mathrm{t})= \\
\ln \left[\frac{\exp (\theta t)-1}{\exp (\theta)-1}\right]\end{array}$ & $\begin{array}{l}\tau=1-\frac{4}{\theta}\left[\mathrm{D}_{1}(-\Theta)\right. \\
-1]\end{array}$ \\
\hline 4 & Clayton & $C_{\Theta}(x, y)=\left[x^{-\theta}+y^{-\theta}-1\right]^{-1 / \theta}$ & $\Phi(\mathrm{t})=\mathrm{t}^{-\Theta}-1$ & $\tau=\frac{\theta}{\theta+1}$ \\
\hline 5 & $\begin{array}{l}\text { Gumbel- } \\
\text { Hoggard }\end{array}$ & $C_{\Theta}(x, y)=\exp \left\{-\left[(-\ln x)^{\Theta}+(-\ln y)^{\Theta}\right]^{1 / \theta}\right\}$ & $\Phi(\mathrm{t})=(-\ln \mathrm{t})^{\Theta}$ & $\tau=1-\Theta^{-1}$ \\
\hline 6 & $\begin{array}{l}\text { Ali- } \\
\text { Mikhail- } \\
\text { Haq }\end{array}$ & $\mathrm{C}_{\Theta}(\mathrm{x}, \mathrm{y})=\frac{x y}{1-\theta(1-x)(1-y)}$ & $\begin{array}{l}\Phi(\mathrm{t})=\ln [ \\
\left.\frac{1-\theta(1-t)}{t}\right]\end{array}$ & $\begin{array}{l}\tau=\left(\frac{3 \theta-2}{\theta}\right)-2 / 3 \\
(1-1 / \theta)^{2} \ln (1- \\
\Theta)\end{array}$ \\
\hline
\end{tabular}

where $F_{1}, \ldots \ldots, F_{p}=$ Marginal distribution functions. If $F_{1}, \ldots \ldots \quad F_{p}$ are continuous then the copula $\mathrm{C}$ is unique and has the representation (Poulin et al., 2007):

$$
\begin{aligned}
\mathrm{C}\left(\mathrm{x}_{1}, \mathrm{x}_{2}, \ldots \ldots \ldots \mathrm{x}_{\mathrm{p}}\right)= & \mathrm{F}\left(\mathrm{F}^{-1}\left(\mathrm{x}_{1}\right), \mathrm{F}^{-1}\left(\mathrm{x}_{2}\right), \ldots \ldots \ldots \ldots \mathrm{F}^{-1}\left(\mathrm{x}_{\mathrm{p}}\right)\right), \\
& 0 \leq \mathrm{x}_{1}, \ldots \ldots \ldots, \mathrm{x}_{\mathrm{p}} \leq 1
\end{aligned}
$$

Copula is expressed for two random variables, $\mathrm{U}$ and $\mathrm{V}$, with their CDFs, respectively, as $\mathrm{F}_{\mathrm{u}}(\mathrm{u})$ and $\mathrm{F}_{\mathrm{v}}(\mathrm{v})$, let $\mathrm{X}=\mathrm{F}_{\mathrm{u}}(\mathrm{u})$ and $\mathrm{Y}=\mathrm{F}_{\mathrm{v}}(\mathrm{v})$, Where, $\mathrm{X}$ and $\mathrm{Y}$ are random variables which is uniformly distributed with their values $\mathrm{x}$ and $\mathrm{y}$. The list copulas and its equations with generating function is shown in Table 1.

Table 1. : List of Copulas and its equation, generating function and relation with $\tau$. 
141 Where,

$142 \Theta=$ Parameter which controlling the dependence between $\mathrm{x}$ and $\mathrm{y}$.

$143 \Phi=$ Generator of the copulas.

144 Debye function is expressed as follows.

$145 \quad D_{n}(\beta, x)=\frac{n}{x^{n}} \int_{0}^{x} \frac{t^{n}}{\left(e^{t}-1\right)^{\beta}} d t$

$146 \quad D_{1}(1, \Theta)=\frac{1}{\Theta} \int_{0}^{\Theta} \frac{t}{e^{t}-1} d t$

147

148 3. Dataset used for Copulas

149 Mean monthly discharge at Farakka barrage data set about twenty-five years from 1949 to 1973

150 data has taken from Water Resources Information System of India at Farakka barrage project,

151 Farakka, West Bengal, India.

152 The observed data set are divided into two parts. One part contains twenty years' data (from

1531949 to 1968 ) has been used for parameter estimation i.e. in model calibration, next five years' data (from1969 to 1973) has been used for model validation and testing. Parameter estimation data is arranged such a way that pre-monsoon (December to May) and post monsoon (June to November) data is separated and making two series of dataset for copulas.

\section{Selection of distribution for Copulas}

For modeling of controlled outflow, bivariate Copula has taken in this study. As Copula accepts CDF of variables, distribution functions of two variables, should be known. The distribution functions are chosen on the basis of AIC, BIC values, k-s test and probability plots. The distributions that are tested to know the parent distribution of two variables are normal distribution, lognormal distribution, extreme value type I distribution, generalized extreme value distribution, gamma distribution, weibull and exponential distributions. We used data set for 

Jun. -Nov. 1968 (Figure 2), Dec. -May 1949 to Dec. -May 1968 (Figure 3), Jun. -Nov. 1949 to Jun. -Nov. 1968 (Figure 4), Dec. -May 1949 to Dec. -May 1968 (Figure 5), Jun.-Nov.1949 to

167 Jun. -Nov. 1968 (Figure 6).

168 The violet colour represents the data set for different times and red colour represents normal 169 distribution, green colour represents lognormal distribution, etc as shown in Figures 1-6. Figure 1 represents cumulative distribution function of data points along with all distributions in pre monsoon seasons (Dec.- May 1949 to Dec.-May 1968).

172 Figure 2 represents cumulative distribution function of data points along with all distributions in 173 post monsoon seasons (Jun. - Nov. 1949 to Jun. - Nov 1968). Figure 3 represents Probability 174 density function of data points along with all distributions in post monsoon seasons (Dec.- May 1949 to Dec.-May 1968). Figure 4 represents Probability density function of data points along with all distributions in post monsoon seasons (Jun. -Nov. 1949 to Jun. -Nov. 1968). Select the standard distribution which is best fit for original data sets. Violet colour of Figure 5 represents the data points and other colour represents the various distributions of mean monthly discharge (Dec. -May 1949 to Dec. -May 1968) Select the best fit standard probability distribution. Violet colour of this Figure 6 represents the data points and other colour represents the various distributions of mean monthly discharge (Jun.-Nov.1949 to Jun. -Nov. 1968). Selection of the distribution function can be based the best fit for original data sets. 
Hydrol. Earth Syst. Sci. Discuss., https://doi.org/10.5194/hess-2018-380

Manuscript under review for journal Hydrol. Earth Syst. Sci.

Discussion started: 12 December 2018

(c) Author(s) 2018. CC BY 4.0 License.

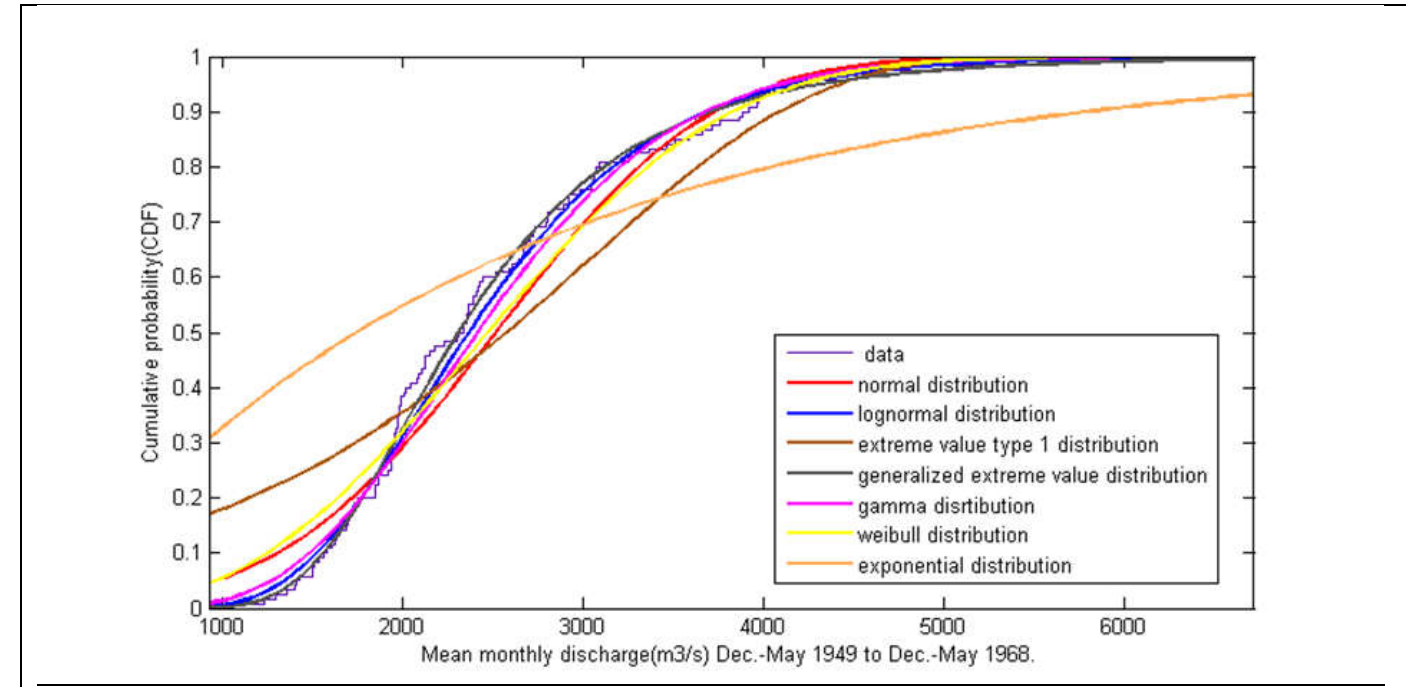

Figure 1. CDF of mean monthly discharge(m³/s) Dec. -May 1949 to Dec. -May 1968.

183

184

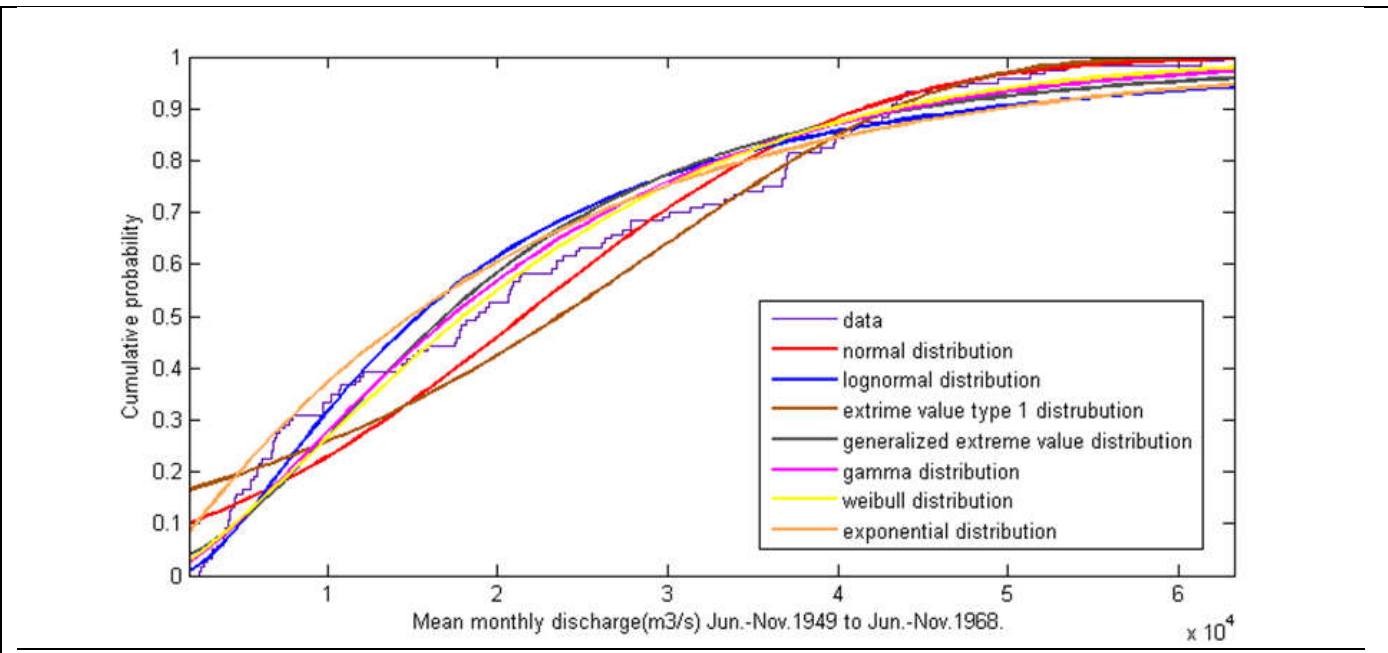

Figure 2. CDF of mean monthly discharge (m³/s) Jun. -Nov. 1949 to Jun. -Nov. 1968. 
Hydrol. Earth Syst. Sci. Discuss., https://doi.org/10.5194/hess-2018-380

Manuscript under review for journal Hydrol. Earth Syst. Sci.

Discussion started: 12 December 2018

(c) Author(s) 2018. CC BY 4.0 License.

192

193

194

195

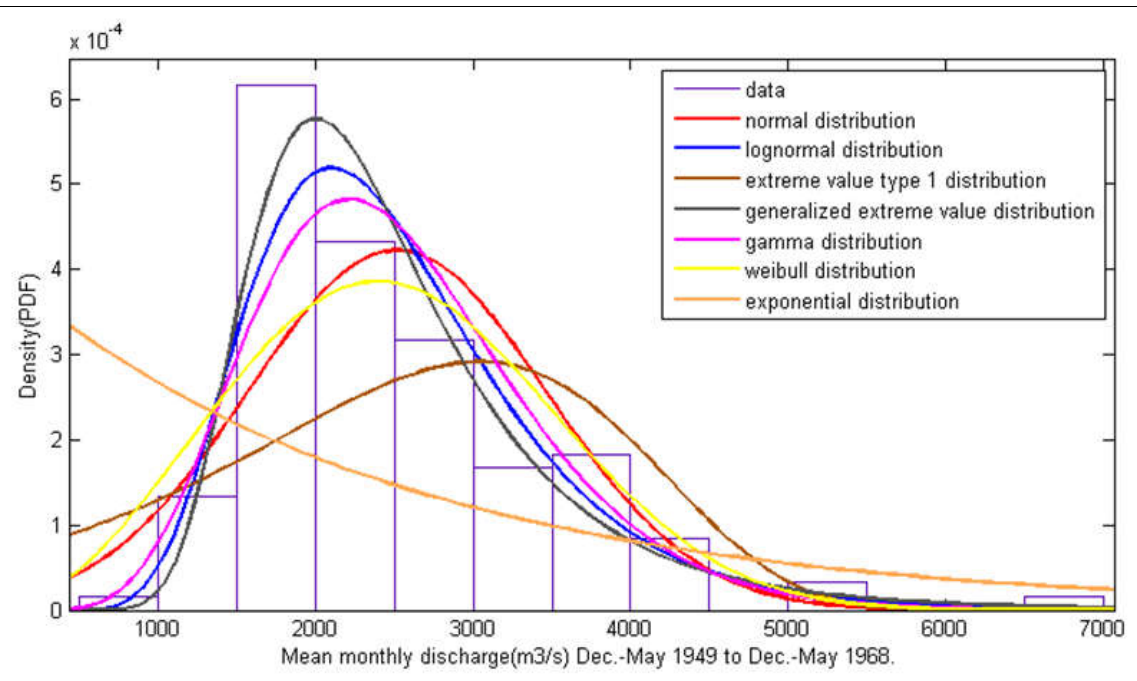

Figure 3. PDF of mean monthly discharge(m³/s) Dec. -May 1949 to Dec. -May 1968.

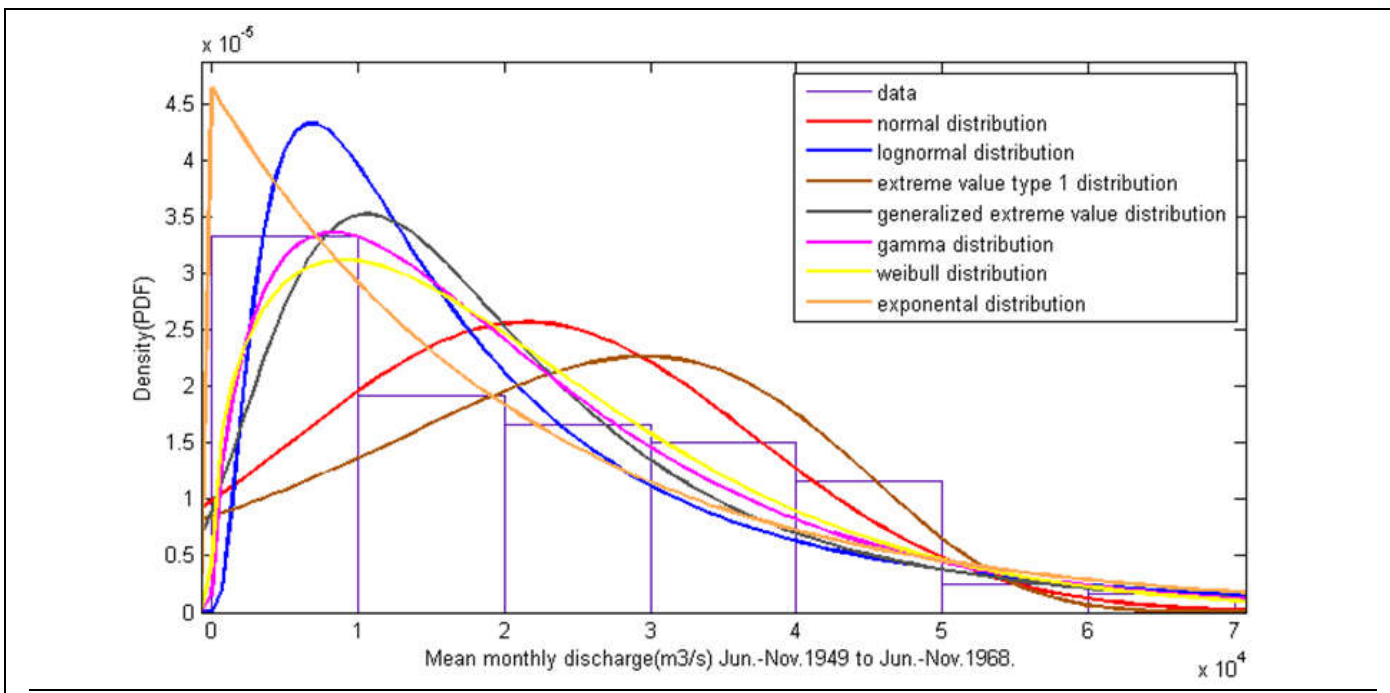

Figure 4. PDF of mean monthly discharge ( $\left.\mathrm{m}^{3} / \mathrm{s}\right)$ Jun. -Nov. 1949 to Jun. -Nov. 1968. 
Hydrol. Earth Syst. Sci. Discuss., https://doi.org/10.5194/hess-2018-380

Manuscript under review for journal Hydrol. Earth Syst. Sci.

Discussion started: 12 December 2018

(c) Author(s) 2018. CC BY 4.0 License.

196

197

198

199

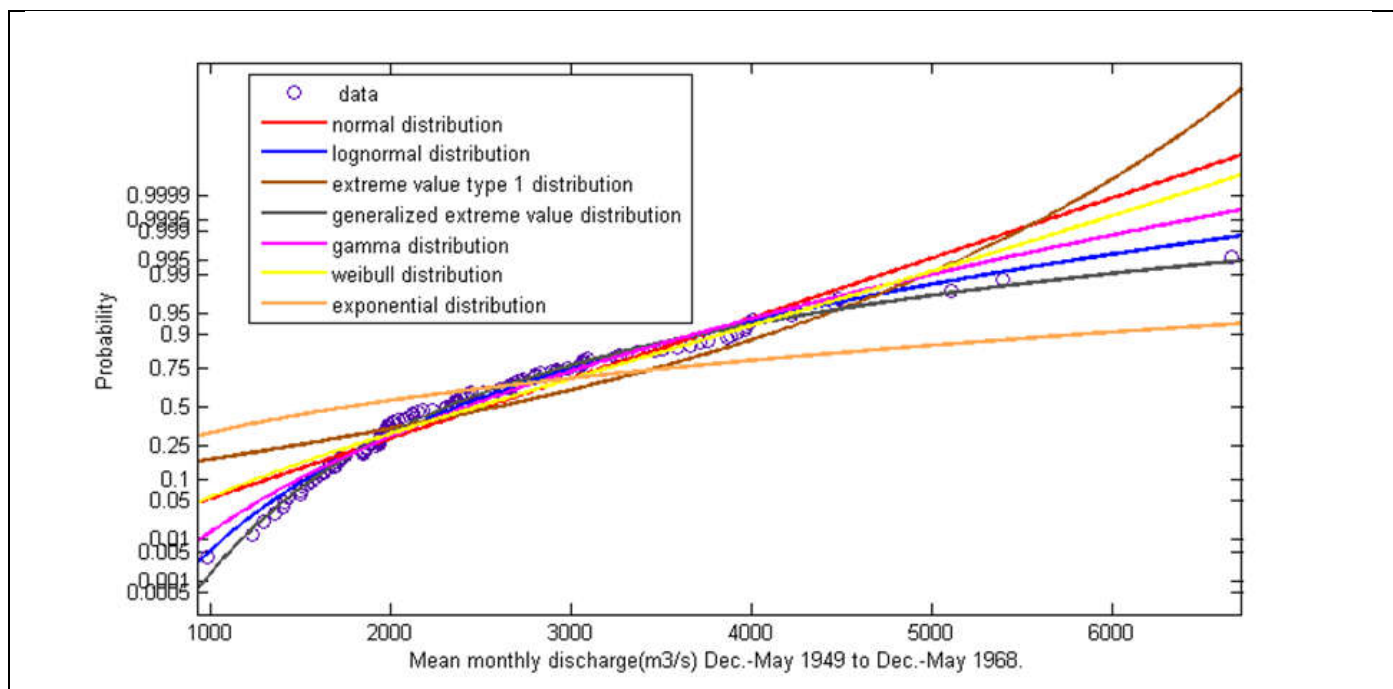

Figure 5. Probability of mean monthly discharge $\left(\mathrm{m}^{3} / \mathrm{s}\right)$ Dec. -May 1949 to Dec. -May 1968.

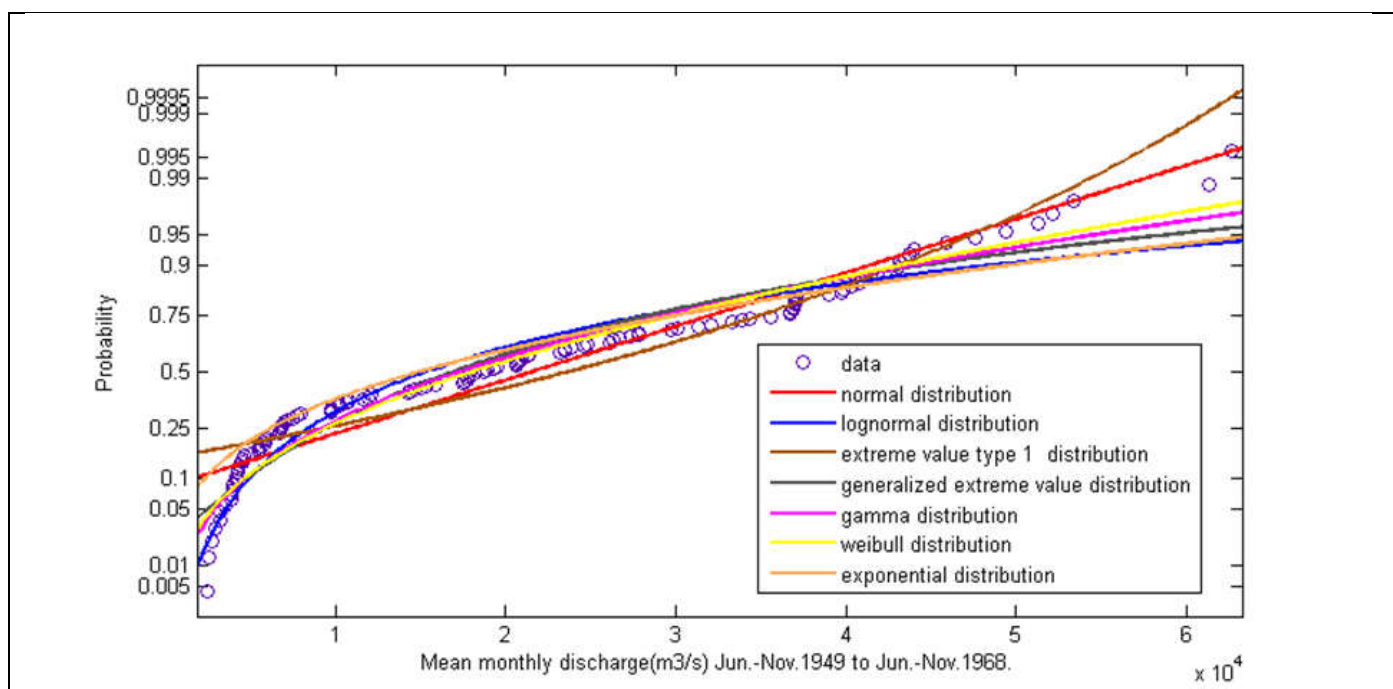

Figure 6. Probability of mean monthly discharge $\left(\mathrm{m}^{3} / \mathrm{s}\right)$ Jun.-Nov.1949 to Jun. -Nov. 1968. 
Hydrol. Earth Syst. Sci. Discuss., https://doi.org/10.5194/hess-2018-380

Manuscript under review for journal Hydrol. Earth Syst. Sci.

Discussion started: 12 December 2018

\subsection{Mean square Error (MSE) or Mean squared deviation (MSD)}

203 It is measurement of the mean of the squares of the errors or deviations i.e., the difference

204 between the estimator and what is estimated value (Table 2). MSE represents the risk function

205 corresponding to the expected value of the squared error loss or quadratic loss. The difference in

206 the MSE because of randomness. Lowest value of AIC is good for model.

$207 \quad \mathrm{MSE}=\Sigma \frac{\left(e_{c d f}-p_{c d f}\right)^{2}}{n}$

208 Where,

$e_{c d f}=$ Empirical Cumulative Density Function

$P_{c d f}=$ Predicted Cumulative Density Function

211

212

213

214

215

216

217 Where,

218

219

220

\subsection{Akaike Information Criterion (AIC)}

For a given data set and given set of models . AIC measures relative quality of statistical methods and it compute the each model's quality, relative to other models quality (Table 2). Hence, AIC criteria is used for model selection and lowest value of AIC is proffered for model. .

$\mathrm{AIC}=\mathrm{n} * \ln (\mathrm{MSE})+2 \mathrm{~K}+\frac{2 \mathrm{~K} *(\mathrm{~K}+1)}{\mathrm{n}-\mathrm{K}-1}$

$\mathrm{n}=$ Number of data points.

$\mathrm{K}=$ Number of parameters. 
Hydrol. Earth Syst. Sci. Discuss., https://doi.org/10.5194/hess-2018-380

Manuscript under review for journal Hydrol. Earth Syst. Sci.

Discussion started: 12 December 2018

(c) Author(s) 2018. CC BY 4.0 License.

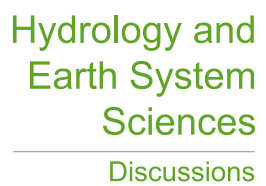

(c) (1)

\section{$221 \quad 4.3$ Bayesian Information Criterion (BIC)}

222 It is a model selection criterion, model is selected among the finite set of model. Model with

223 lowest value of BIC is preferred (Table 2). It is mainly based on likelihood function and it having

224 approximate same conditions as Akaike information criterion (AIC).

$225 \quad \mathrm{BIC}=\mathrm{n} * \ln (\mathrm{MSE})+\mathrm{K} * \ln (\mathrm{n})$

226 Where,

$227 \quad n=$ Number of data points.

$228 \mathrm{~K}=$ Number of parameters. 
Hydrol. Earth Syst. Sci. Discuss., https://doi.org/10.5194/hess-2018-380

Manuscript under review for journal Hydrol. Earth Syst. Sci.

Discussion started: 12 December 2018

(c) Author(s) 2018. CC BY 4.0 License.

Table 2. Statistic of distributions of data.

\begin{tabular}{|c|c|c|c|c|}
\hline Data & Distribution & MSE & AIC & BIC \\
\hline June-Nov. & Normal & 0.19185140 & -194.02150 & -188.54911 \\
\hline Dec. -May & Normal & 0.18211572 & -200.27095 & -194.79857 \\
\hline June-Nov. & Lognormal & 0.19240251 & -193.67728 & -188.20489 \\
\hline Dec. -May & Lognormal & 0.19197824 & -193.94219 & -188.46980 \\
\hline June-Nov. & Extreme value type 1 & 0.17340721 & -206.15091 & -200.67853 \\
\hline Dec. -May & Extreme value type 1 & 0.14660442 & -226.29948 & -220.82709 \\
\hline June-Nov. & Gen.extreme value & $\mathbf{0 . 0 9 8 7 5 0 2 0}$ & $\mathbf{- 2 7 1 . 6 1 2 5 2}$ & $\mathbf{- 2 6 3 . 4 5 6 9 4}$ \\
\hline Dec. -May & Gen. extreme value & $\mathbf{0 . 0 9 9 1 4 0 0 8}$ & $\mathbf{- 2 7 1 . 1 3 9 6 7}$ & $\mathbf{- 2 6 2 . 9 8 4 0 9}$ \\
\hline June-Nov. & Gamma & 0.19490464 & -192.12678 & -186.65439 \\
\hline Dec.-May & Gamma & 0.19024585 & -195.02997 & -189.55758 \\
\hline June-Nov. & Weibull & 0.19556132 & -191.72315 & -186.25077 \\
\hline Dec.-May & Weibull & 0.17272273 & -206.62552 & -201.15314 \\
\hline June-Nov. & Exponential & 0.16679494 & -212.88491 & -210.13132 \\
\hline Dec.-May & Exponential & 0.11907597 & -253.32532 & -250.57173 \\
\hline June-Nov. & Kernel_normal & 0.16931844 & -211.08299 & -208.32939 \\
\hline June-Nov. & Kernel_box & 0.16880085 & -211.45037 & -208.69678 \\
\hline June-Nov. & Kernel_triangle & 0.16920205 & -211.16550 & -208.41191 \\
\hline June-Nov. & Kernel_epanechnikov & 0.16901130 & -211.30086 & -208.54727 \\
\hline Dec. -May & Kernel_normal & 0.18343705 & -201.47214 & -198.71855 \\
\hline Dec. -May & Kernel_box & 0.18311280 & -201.68445 & -198.93085 \\
\hline Dec. -May & Kernel_triangle & 0.18327642 & -201.57727 & -19882367 \\
\hline Dec. -May & Kernel_epanechnikov & 0.18321604 & -201.61681 & -198.86322 \\
\hline & & & & -2019 \\
\hline
\end{tabular}


Hydrol. Earth Syst. Sci. Discuss., https://doi.org/10.5194/hess-2018-380

Manuscript under review for journal Hydrol. Earth Syst. Sci.

Discussion started: 12 December 2018

(C) Author(s) 2018. CC BY 4.0 License.

\subsection{Kolmogorov - Smirnov test}

The Kolmogorov-Smirnov test (K-S test or KS test) is a nonparametric test of the equality of continuous, one-dimensional probability distributions that can be used to compare a sample with a reference probability distribution (one-sample $\mathrm{K}-\mathrm{S}$ test), or to compare two samples (twosample $\mathrm{K}-\mathrm{S}$ test) (Table 3). The two-sample $\mathrm{K}-\mathrm{S}$ test is one of the most useful and general nonparametric methods for comparing two samples, as it is sensitive to differences in both location and shape of the empirical cumulative distribution functions of the two samples. In the Figure 7 and 8, green colour shows empirical CDF and red colour shows generalized extreme value of CDF. On the basis of Figure 7, generalized extreme value distribution is representing best fit for cumulative distribution function (Jun.-Nov.1949 to Jun. -Nov. 1968). Further, on the basis of Figure 8, generalized extreme value distribution is represents best fit for cumulative distribution function (Dec. -May 1949 to Dec. -May 1968).

Table 3. k-s statistics of distributions of data.

\begin{tabular}{|c|c|c|c|c|c|}
\hline & & & K - S & Test & \\
\hline Data & Distribution & H & $\mathbf{p}$ & $\mathbf{k - s}$ & $\mathbf{c v}$ \\
\hline June-Nov. & Normal & 0 & 0.0509 & 0.1222 & 0.1225 \\
\hline Dec.-May & Normal & 1 & 0.0336 & 0.129 & 0.1225 \\
\hline June-Nov. & Lognormal & 0 & 0.0691 & 0.117 & 01225 \\
\hline Dec.-May & Lognormal & 0 & 0.3695 & 0.0824 & 0.1225 \\
\hline June-Nov. & Extreme value type 1 & 1 & 0.0015 & 0.1712 & 0.1225 \\
\hline Dec.-May & Extreme value type 1 & 1 & 0.000055 & 0.207 & 0.1225 \\
\hline June-Nov. & Gen. extreme value & $\mathbf{0}$ & $\mathbf{0 . 0 9 2}$ & $\mathbf{0 . 1 1 1 8}$ & $\mathbf{0 . 1 2 2 5}$ \\
\hline Dec.-May & Gen. extreme value & $\mathbf{0}$ & $\mathbf{0 . 6 6 9}$ & $\mathbf{0 . 0 6 4 9}$ & $\mathbf{0 . 1 2 2 5}$ \\
\hline June-Nov. & Gamma & 0 & 0.1526 & 0.1021 & 0.1225 \\
\hline Dec.-May & Gamma & 0 & 0.1784 & 0.0989 & 0.1225 \\
\hline
\end{tabular}


Hydrol. Earth Syst. Sci. Discuss., https://doi.org/10.5194/hess-2018-380

Manuscript under review for journal Hydrol. Earth Syst. Sci.

Discussion started: 12 December 2018

(C) Author(s) 2018. CC BY 4.0 License.

\begin{tabular}{|c|c|c|c|c|c|}
\hline June-Nov. & Weibull & 0 & 0.1162 & 0.1075 & 0.1225 \\
\hline Dec.-May & Weibull & 0 & 0.1046 & 0.1095 & 0.1225 \\
\hline June-Nov. & Exponential & 0 & 0.0748 & 0.1156 & 0.1225 \\
\hline Dec.-May & Exponential & 1 & $6.16 \mathrm{E}-17$ & 0.3939 & 0.1225 \\
\hline June-Nov. & Kernel_normal & 1 & 0.0286 & 0.1315 & 0.1225 \\
\hline June-Nov. & Kernel_box & 1 & 0.0141 & 0.1421 & 0.1225 \\
\hline June-Nov. & Kernel_triangle & 1 & 0.0255 & 0.1333 & 0.1225 \\
\hline June-Nov. & Kernel_epanechnikov & 1 & 0.0195 & 0.1374 & 0.1225 \\
\hline Dec.-May & Kernel_normal & 0 & 0.8141 & 0.0567 & 0.1225 \\
\hline Dec.-May & Kernel_box & 0 & 0.8095 & 0.057 & 0.1225 \\
\hline Dec.-May & Kernel_triangle & 0 & 0.8221 & 0.0562 & 0.1225 \\
\hline Dec.-May & Kernel_epanechnikov & 0 & 0.8074 & 0.0571 & 0.1225 \\
\hline
\end{tabular}


Hydrol. Earth Syst. Sci. Discuss., https://doi.org/10.5194/hess-2018-380

Manuscript under review for journal Hydrol. Earth Syst. Sci.

Discussion started: 12 December 2018

(c) Author(s) 2018. CC BY 4.0 License.

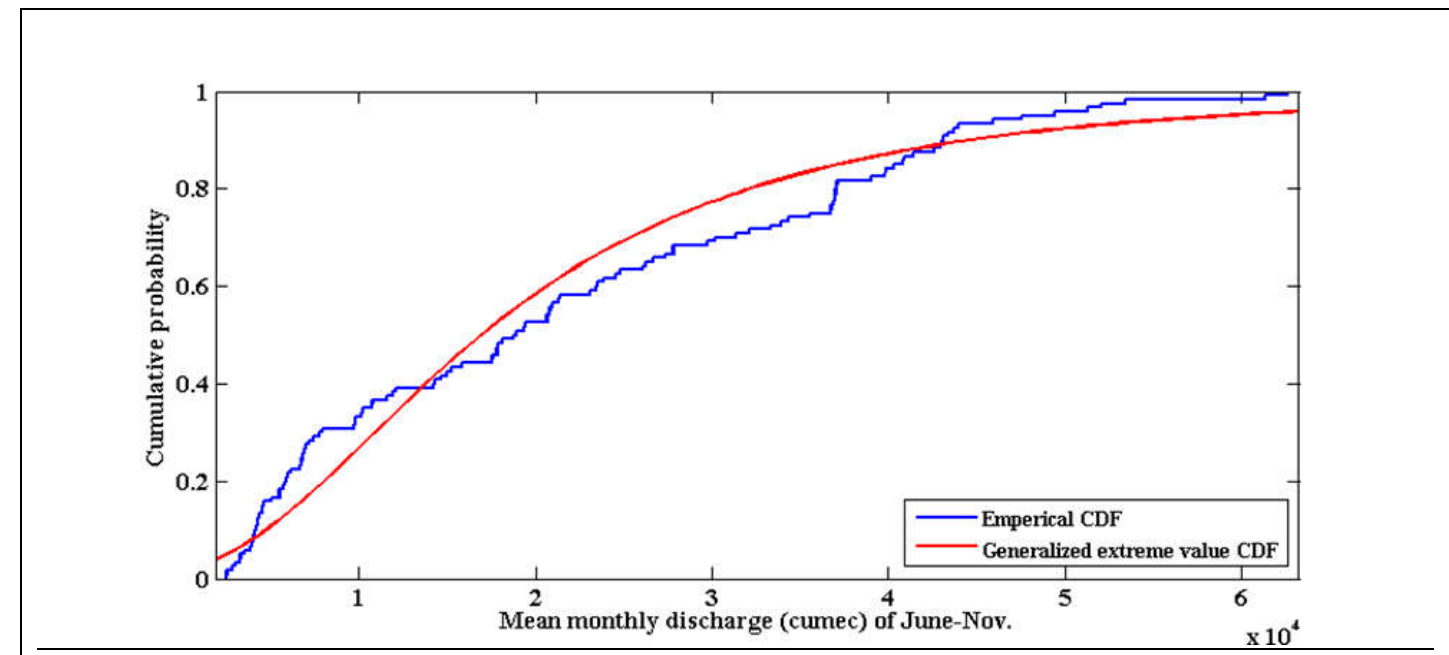

Figure 7. CDF of GEV distribution for Jun.-Nov.1949 to Jun. -Nov. 1968. data.

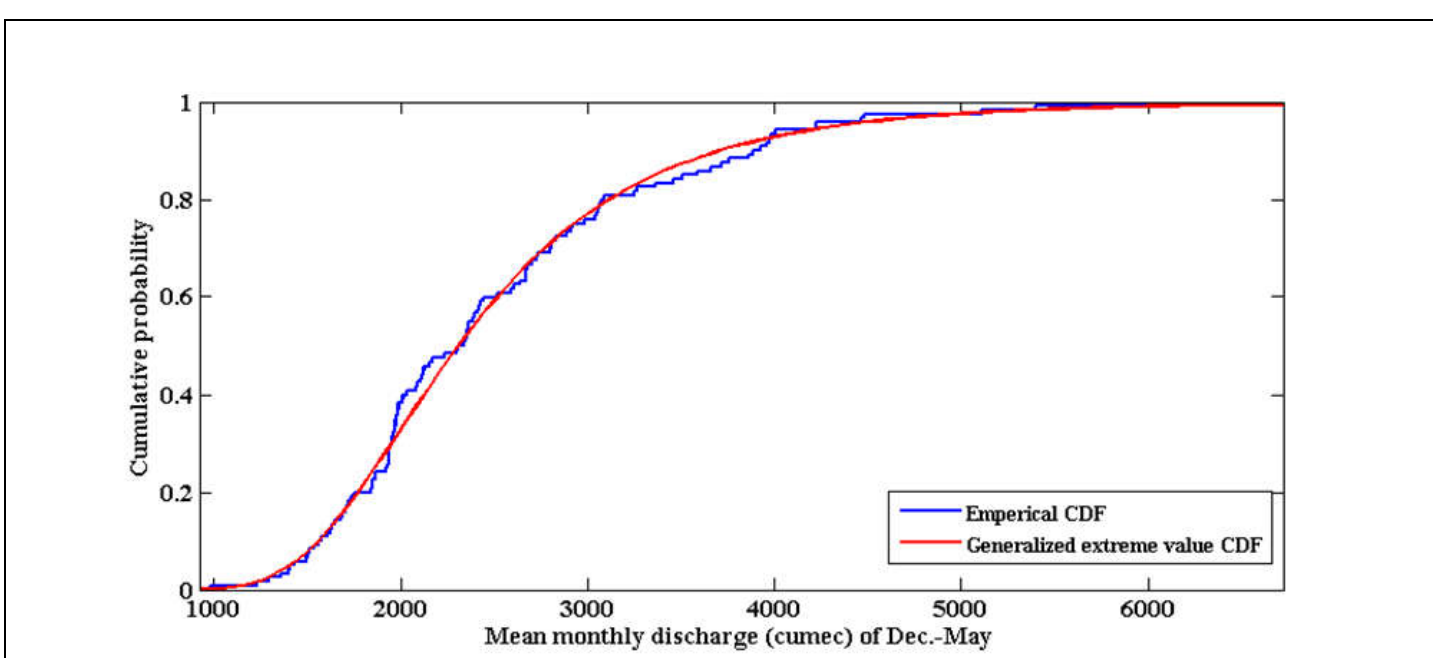

Figure 8. CDF of GEV distribution for ( Dec. -May 1949 to Dec. -May 1968) data. 
Hydrol. Earth Syst. Sci. Discuss., https://doi.org/10.5194/hess-2018-380

Manuscript under review for journal Hydrol. Earth Syst. Sci.

Discussion started: 12 December 2018

(c) Author(s) 2018. CC BY 4.0 License.
Hydrology and
252

253

\begin{tabular}{|c|c|c|c|c|c|c|}
\hline & Parameter & & & & & \\
\hline Copula & & & & & & \\
\hline model & rho & nu & MLE & MSE & AIC & $\mathrm{BIC}$ \\
\hline Gaussian & -0.2338 & & 3.38 & 0.002125 & -736.448 & -732.69 \\
\hline $\mathrm{t}$ & -0.2344 & $3.79 \mathrm{E}+06$ & 3.37 & 0.002126 & -734.331 & -731.65 \\
\hline Frank & -1.1424 & & 4.557 & 0.00206 & -740.190 & -736.44 \\
\hline $\mathrm{AMH}$ & -1 & & 2.284 & 0.002072 & -739.477 & -735.72 \\
\hline Clayton & 1. $45 \mathrm{E}-06$ & & 0.6685 & 0.002209 & -731.817 & -728.06 \\
\hline $\mathrm{GH}$ & 1 & & $-7.2 \mathrm{E}-07$ & 0.002201 & -732.216 & -728.46 \\
\hline
\end{tabular}

\section{Copula parameter estimation}

Table 4. : Copulas and its parameter.
254

255

256 For a best copula model MLE should be high and MSE, AIC, BIC should be minimum from the

257 above data frank is best model for predicting the data (Table 4). Figure 9 shows the probability 
Hydrol. Earth Syst. Sci. Discuss., https://doi.org/10.5194/hess-2018-380

Manuscript under review for journal Hydrol. Earth Syst. Sci.

Discussion started: 12 December 2018

(C) Author(s) 2018. CC BY 4.0 License.
Hydrology and

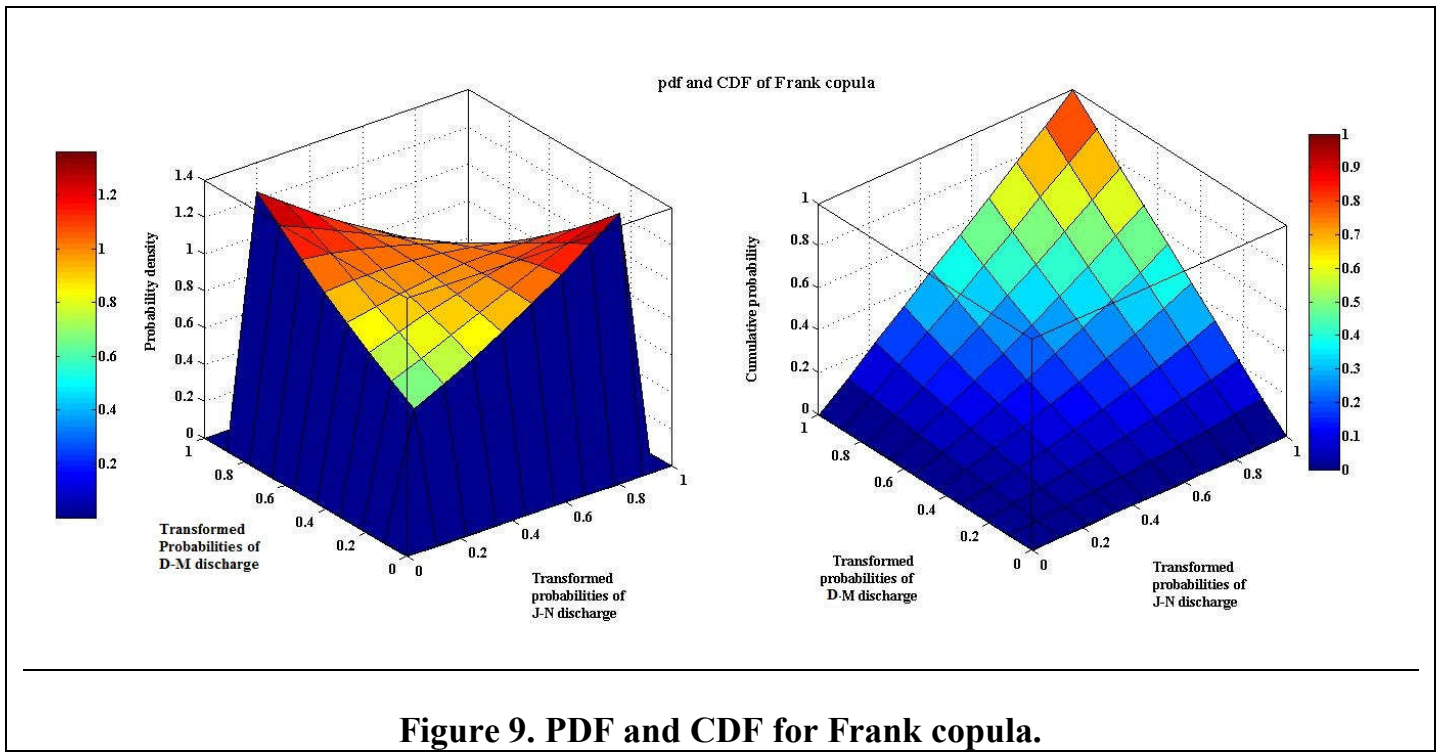

262

263

264

265

266

\section{Validation test of Copula}

Validation test of Frank Copula is performed by comparing observed and empirical CDF in calibration and validation test. Here, observed CDF is CDF of Frank Copula and Empirical CDF is taken from some non-parametric method (Table 5). Formula of empirical CDF of copula is given below. In the Figure 10, the blue points shows data points at calibration and validation state. Blue points represents data points in calibrated and validation stage by Frank copula as shown in Figure 10.

Table 5. : Statistics in calibration and validation test.

\begin{tabular}{|l|l|l|}
\hline Statistics & Calibration Test & Validation Test \\
\hline MSE & 0.00206 & 0.00147 \\
\hline $\mathrm{R}^{\wedge} 2$ & 0.94 & 0.9 \\
\hline
\end{tabular}



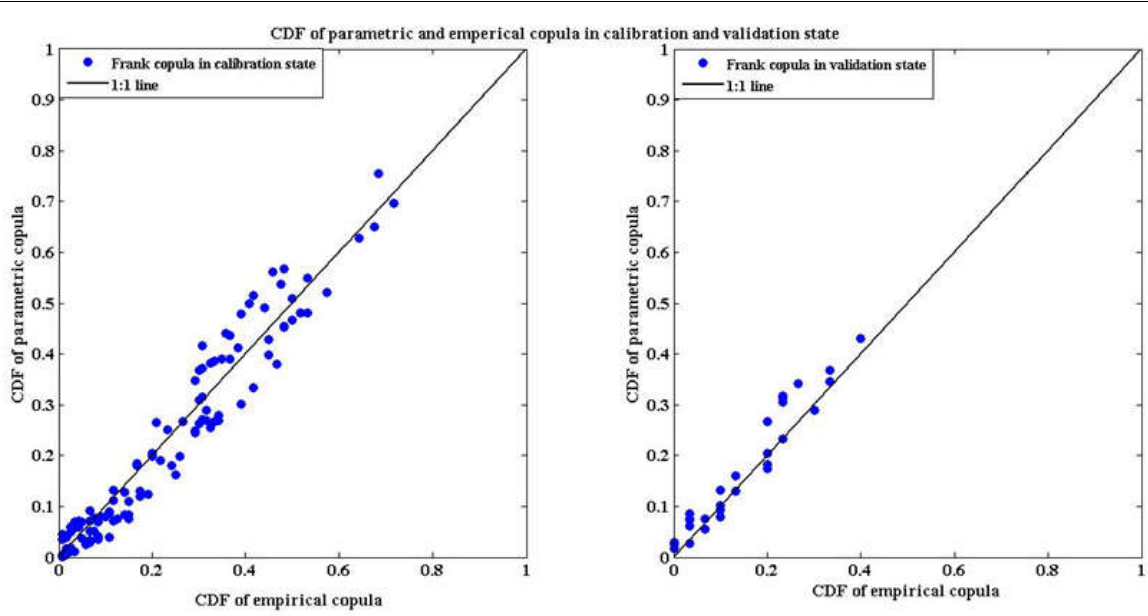

Figure 10. CDF of observed and empirical copula in calibration and validation state.

\section{Statistical Approach for ARMA}

In this approach linear type stationary ARMA models are fitted by observed discharge data where stationary means the ARMA models that are generated from a time series does not changing its underlying probability distribution function (pdf) from which different values of time series are pulled out. In loose sense stationarity indicates time series has constant mean and variance throughout the process where time series is the collection of random variables, plotted corresponding of its time, follow on their own distribution (figure. 11). In ARMA model AR i.e. auto regressive term indicates lag of time series value and moving average is the lag in error term. Generally, ARIMA is conventional class of model where "I" integration term indicates order of difference required to do the time series stationary but in this study it is done by normalizing all the discharge data through its long term mean and standard deviation (figure. 12). The mathematical form of normalization is given below.

$$
Z_{i}=\frac{X_{i}-\bar{X}}{\sigma_{i}}
$$


290 Where, $\mathrm{Xi}=$ Value of mean monthly discharge, $\overline{\mathrm{X}}=$ Long term average, $\sigma i=$ Long term standard

291 deviation, $\mathrm{i}=1$ to $\mathrm{N}, \mathrm{N}$ is total number of data point in monthly step. The normalization or

292 differencing in the data is not only make it stationary but also removes periodicity from the time

293 series where periodicity can be defined as correlation i.e. linear association of data with the previous some lag value of data. As we are interested to only capture unknown information from a process which are unknown due to noise or random term (stochastic factor in the process), so deterministic part in terms of long term mean, periodicity, seasonality, trend, sudden drop or jump is necessary to remove from the time series since these deterministic terms already reflects known information about the process, are not required to model. Generally monthly discharge time series shows periodicity and seasonality in the data set and it is necessary to remove before calibrate (finding Parameter of model) to ARMA model as this type of model is developed to capture unknown information from noise i.e. random process.

The observed data set are divided into two parts. One part contains twenty years' data (from 1949 to 1968 ) has been used for parameter estimation i.e. in model calibration, next five years' data (from1969 to 1973) has been used for model validation and testing. The mean monthly discharge data used for model calibration may have serial correlation i.e. any data in particular time step depends on its previous adjacent data and may follow so on. The time series plot of observe discharge depicts this serial correlation, seasonality or periodicity in terms of information contain in the series by showing some regularity or similar oscillation of the series. 
Hydrol. Earth Syst. Sci. Discuss., https://doi.org/10.5194/hess-2018-380

Manuscript under review for journal Hydrol. Earth Syst. Sci.

Discussion started: 12 December 2018

(c) Author(s) 2018. CC BY 4.0 License.
Hydrology and

Earth System

Sciences

Discussions

(c) (1)

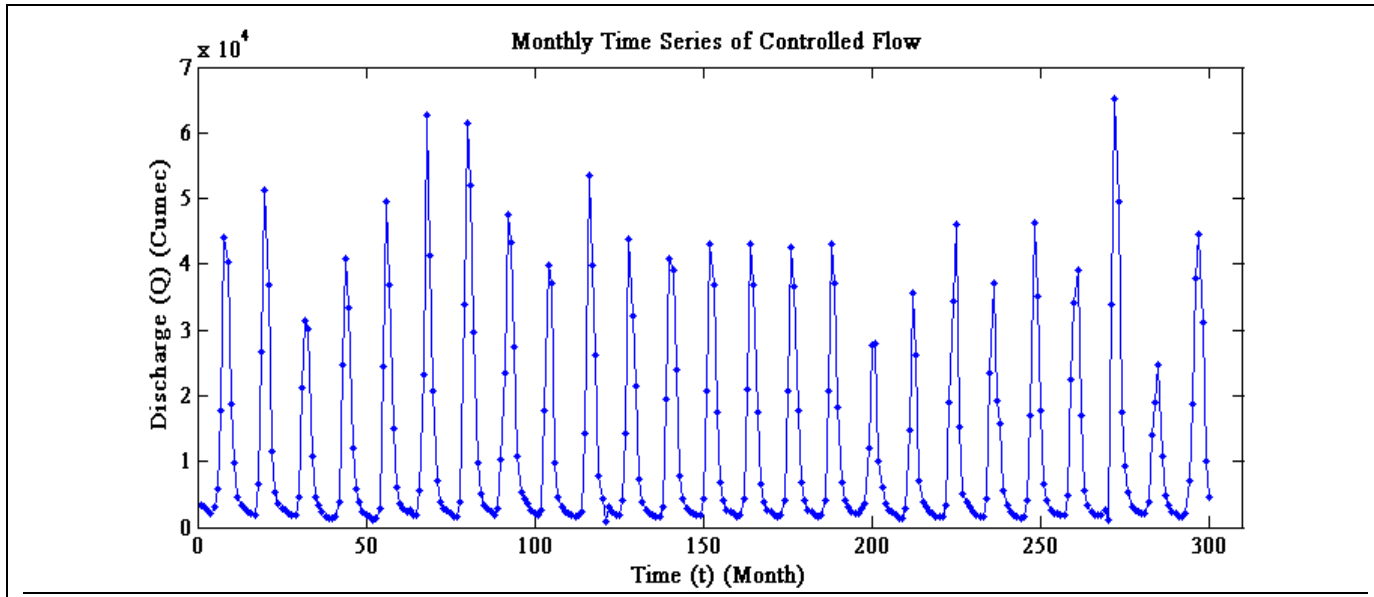

Figure 11: Time series plot of discharge (cumec) starting from (Jan. 1949 to Dec. 1973).

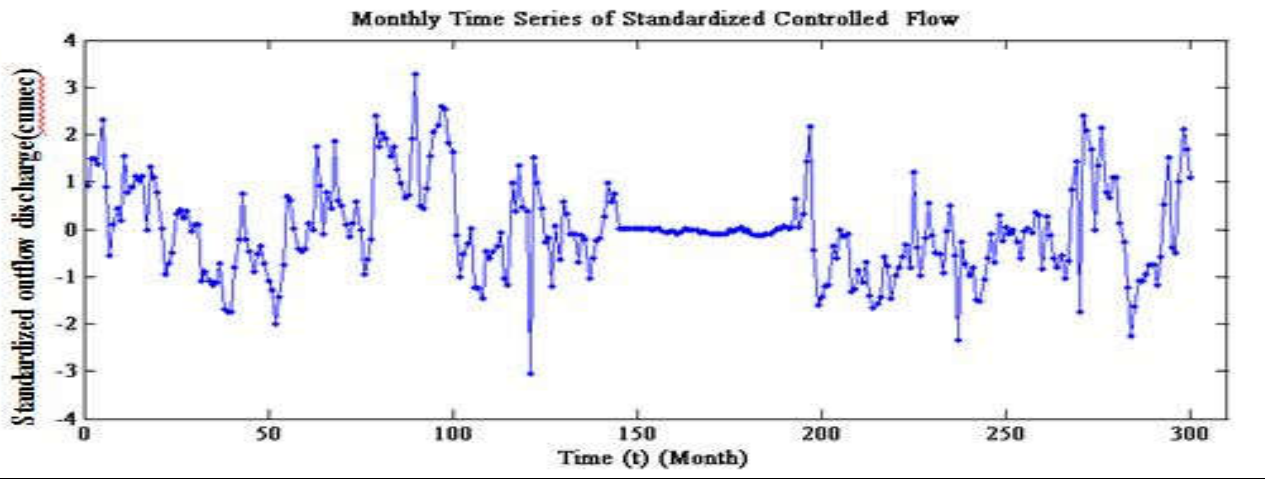

Figure 12: Time series plot of Standardized discharge (cumec) starting from (Jan. 1949 to Dec. 1973).

310

311

312

\section{Spectral Analysis}

The observe time series is analyzed in frequency domain to indicate exactly in which months periodicity present in the data that is only indicates by correlogram. In this frequency domain 
316 analysis an assumption is taken as time series is a random sample of a process over time and is made up of oscillations of all possible frequencies. The time series is approximated by signal process contains deterministic term in wave form and noise or random term by which the information is extracted from time series and shows prominent spike in variance spectrum plot. The contributing equations for spectral analysis are given below

$\mathrm{X}_{\mathrm{t}}=\alpha_{0}+\sum_{\mathrm{k}=1}^{\mathrm{n}-1 / 2, \mathrm{n} / 2}\left[\alpha_{\mathrm{k}} \cos \left(2 \pi \mathrm{f}_{\mathrm{k}} \mathrm{t}\right)+\beta_{\mathrm{k}} \sin \left(2 \pi \mathrm{f}_{\mathrm{k}} \mathrm{t}\right)\right]+\varepsilon_{\mathrm{t}}$

$\mathrm{f}_{\mathrm{k}}=\frac{\mathrm{k}}{\mathrm{N}} ; \mathrm{P}=\frac{1}{\mathrm{f}_{\mathrm{k}}} ; \alpha_{0}=\overline{\mathrm{x}}$

$\alpha_{\mathrm{k}}=\frac{2}{\mathrm{~N}} \sum_{\mathrm{i}=1}^{\mathrm{n}} \mathrm{x}_{\mathrm{t}} \cos \left(2 \pi \mathrm{f}_{\mathrm{k}}\right) \quad \mathrm{k}=1,2,3, \ldots \ldots . \mathrm{M}$

$$
\beta_{\mathrm{k}}=\frac{2}{\mathrm{~N}} \sum_{\mathrm{i}=1}^{\mathrm{n}} \mathrm{x}_{\mathrm{t}} \sin \left(2 \pi \mathrm{f}_{\mathrm{k}}\right) \quad \mathrm{k}=1,2,3, \ldots \ldots \mathrm{M}
$$

Where;

$\mathrm{N}=$ Observation numbers, $\mathrm{X}_{\mathrm{t}}=$ Observe rainfall data, $\mathrm{t}=$ Time step in month

$\mathrm{P}=$ Periodicity in the data, $\overline{\mathrm{X}}=$ Mean of the series (average monthly rainfall)

$\alpha_{\mathrm{k}}=$ Cosine wave form, $\beta_{\mathrm{k}}=$ Sine wave form of time series.

$\mathrm{M}=$ Maximum lag typically consider $0.25 \mathrm{~N}$.

Values of $\alpha_{\mathrm{k}}$ and $\beta_{\mathrm{k}}$ in equation number 7 are valid up to $\mathrm{k}=\mathrm{N} / 2$.

\subsection{Line spectrum}

The spike in the line spectrum confirms the presence of particular month periodicity in the data

(Figure 13 and Table 6 )and lime spectrum is plot between spectral density versus angular 
Hydrol. Earth Syst. Sci. Discuss., https://doi.org/10.5194/hess-2018-380

337 frequency. It is also known as variance spectrum. Line spectrum plot is drawn by using discharge 338 data and standardized discharge data.

344

345

346

347

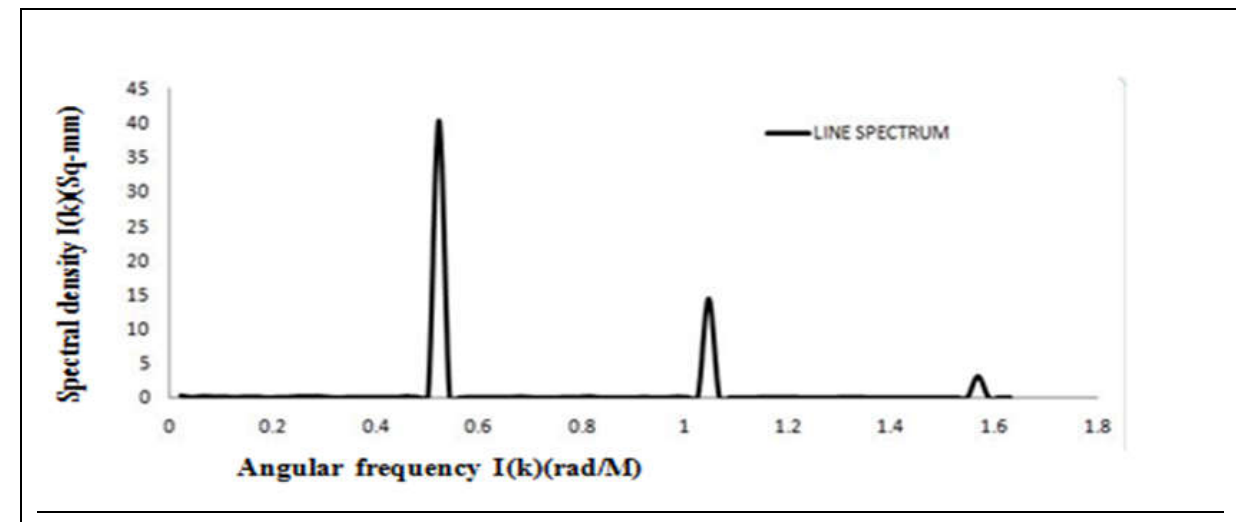

Figure 13: Plot of spectral density versus angular frequency. 
Hydrol. Earth Syst. Sci. Discuss., https://doi.org/10.5194/hess-2018-380

Table 6: Showing the spectral density and frequency data corresponding to spikes.

\begin{tabular}{|l|l|l|l|}
\hline Spike & $\begin{array}{l}\text { Spectral density }\left(\mathbf{I}_{\mathbf{k}}\right) \\
(\mathbf{s q}-\mathbf{m m})\end{array}$ & $\begin{array}{l}\text { Angular frequency } \\
\left(\boldsymbol{\omega}_{\boldsymbol{k}}\right)(\mathbf{r a d} / \mathbf{M})\end{array}$ & Periodicity (Months) \\
\hline 1 & $4.05 * 10^{10}$ & 0.52 & 12 \\
\hline 2 & $4.48 * 10^{9}$ & 1.05 & 6 \\
\hline 3 & $4.60 * 10^{9}$ & 1.6 & 4 \\
\hline
\end{tabular}

351

\section{Model Description}

Auto regressive moving average models are developed using white noise series. In the present study the information form observed time series has captured not only developing ARMA (p, q) model but also by pure AR (p) and MA (q) model. The block diagram for AR (p), MA (q) and $\operatorname{ARMA}(\mathrm{p}, \mathrm{q})$ process are shown below.

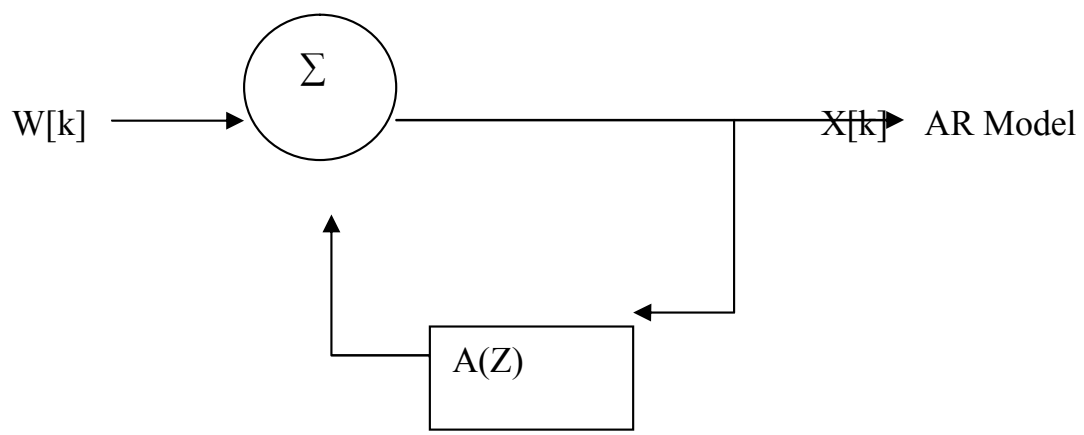


367

368

369

370

371

372

373

374

375

376

377

378

379

$\mathrm{X}[\mathrm{k}]=\sum \mathrm{an} * \mathrm{X}[\mathrm{k}-\mathrm{n}]+\mathrm{W}[\mathrm{k}]$, where $\mathrm{X}[\mathrm{k}]=$ Discrete value or $\mathrm{k}^{\text {th }}$ sequence of random variable (discharge), an $=A R$ parameter for $n$th order sum over $n=1$ to $N, N=$ number of data point, $X[k-$ $\mathrm{n}]=\mathrm{nth}$ lag of random variable (discharge), $\mathrm{A}(\mathrm{Z})=\mathrm{AR}$ polynomial equation, $\mathrm{W}[\mathrm{k}]=$ Error term associated in the model prediction.

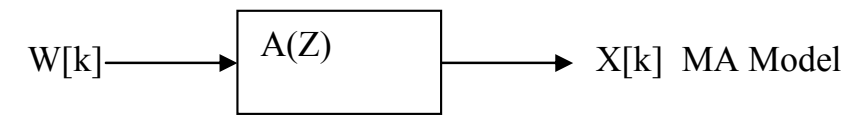

$\mathrm{X}[\mathrm{k}]=\sum \mathrm{bn} * \mathrm{~W}[\mathrm{k}-\mathrm{n}]$, where $\mathrm{X}[\mathrm{k}]=$ Discrete value or kth sequence random variable (rainfall), $\mathrm{bn}=$ MA parameter for $n$th order sum over $n=0$ to $M-1, M=$ number of error point, $W[k-n]=n$th lag of white noise or error term, $\mathrm{B}(\mathrm{Z})=\mathrm{MA}$ polynomial equation, $\mathrm{W}[\mathrm{k}]=$ Error term associated in the model prediction.

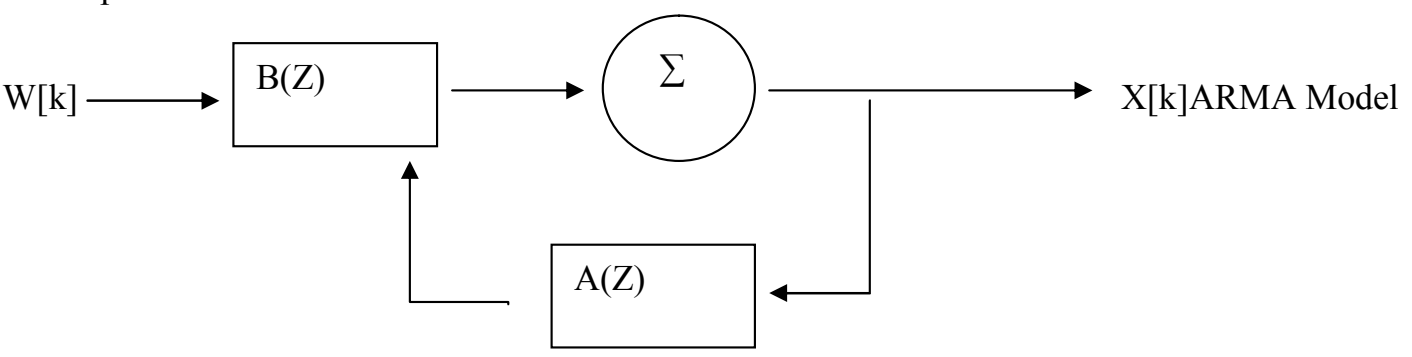

$\mathrm{X}[\mathrm{k}]=\sum \mathrm{an} * \mathrm{X}[\mathrm{k}-\mathrm{n}]+\sum \mathrm{bn} * \mathrm{~W}[\mathrm{k}-\mathrm{n}]$, where $\mathrm{X}[\mathrm{k}]=$ Discrete value or kth sequence of random variable (discharge), an $=\mathrm{AR}$ parameter for $\mathrm{nth}$ order, $\mathrm{X}[\mathrm{k}-\mathrm{n}]=\mathrm{nth}$ lag of random variable (discharge) sum over for $\mathrm{n}=1$ to $\mathrm{N}, \mathrm{N}=$ number of data point, a $(\mathrm{Z})=\mathrm{AR}$ polynomial equation, $\mathrm{W}[\mathrm{k}]=$ Error term associated in the model prediction (white noise), bn = MA parameter for $\mathrm{nth}$ order sum over $\mathrm{n}=0$ to $\mathrm{M}-1, \mathrm{M}=$ number of error point, $\mathrm{W}[\mathrm{k}-\mathrm{n}]=\mathrm{nth}$ lag of white noise or error term, $\mathrm{B}(\mathrm{Z})=\mathrm{MA}$ polynomial equation. 
400

401

402

$\operatorname{An} \operatorname{ARMA}(p, q)$ model which having autoregressive order i.e. $p$ and moving average order i.e. $\mathrm{q}$ can be expressed as following from of equation.

$\mathrm{X}_{\mathrm{t}}-\Phi_{1} \mathrm{X}_{\mathrm{t}-1}-\Phi_{2} \mathrm{X}_{\mathrm{t}-2}-\ldots . .-\Phi_{\mathrm{p}} \mathrm{X}_{\mathrm{t}-\mathrm{p}}=\varepsilon_{\mathrm{t}}+\Theta_{1} \varepsilon_{\mathrm{t}-1}+\Theta_{2} \varepsilon_{\mathrm{t}-2}+\ldots .+\Theta_{\mathrm{p}} \varepsilon_{\mathrm{t}-\mathrm{p} 4}$

$\Phi(\mathrm{L}) \mathrm{X}_{\mathrm{t}}=\Theta(\mathrm{L}) \varepsilon_{\mathrm{t}}, \Phi(\mathrm{L})=1-\sum_{j=1}^{p} \Phi_{\mathrm{j}} L^{j}$ and $\Theta(\mathrm{L})=\sum_{j=0}^{q} \Theta_{\mathrm{j}} L^{j}$

Where, Back shift operator $L^{j} \mathrm{X}_{\mathrm{t}}=\mathrm{X}_{\mathrm{t}-\mathrm{j}}$, it shift the value for $\mathrm{j}$ th lag.

\section{Model Calibration}

Two types of model (prediction model) has developed using white noise series but model identification and parameter estimation are not done by conventional Box-Jenkins and YuleWalker method. In this present study model identification has done by picking up some candidate ARMA model of order up to ten and five for AR and MA process as for most hydrologic cases AR parameter (table 7) and MA parameter (table 8). The model selection is based maximum likelihood estimate (MLE) criteria for prediction model. The underlying equations for MLE criteria for model selection which are used for present study has given in following form.

MLE criteria: $\operatorname{MLE}=-\frac{\mathrm{N}}{2} \ln \left(\sigma_{\mathrm{i}}\right)-\mathrm{n}_{\mathrm{i}}$

Where, $\mathrm{N}$ is the total data sets those are used for model calibration, $\sigma_{\mathrm{i}}$ is the variance of residual series where residual is the difference between observe data and corresponding to model output and $n_{i}$ is the total number of parameter of a model.

The parameter, MLE values for candidate models are shown in table below. 
Hydrol. Earth Syst. Sci. Discuss., https://doi.org/10.5194/hess-2018-380

Manuscript under review for journal Hydrol. Earth Syst. Sci.

Discussion started: 12 December 2018

(c) Author(s) 2018. CC BY 4.0 License.
Hydrology and

Earth System

Sciences

Discussions

Table 7: Showing only AR parameter for ARMA model.

\begin{tabular}{|c|c|c|c|c|c|c|c|c|c|c|}
\hline & & & AR PARA & IETERS & & & & & & \\
\hline MODELS & $\phi 1$ & $\phi 2$ & $\phi 3$ & $\phi 4$ & $\phi 5$ & $\phi 6$ & $\phi 7$ & $\phi 8$ & $\phi 9$ & $\phi 10$ \\
\hline $\operatorname{ARMA}(1,0)$ & 0.66451 & & & & & & & & & \\
\hline $\operatorname{ARMA}(2,0)$ & 0.60492 & 0.09057 & & & & & & & & \\
\hline $\operatorname{ARMA}(3,0)$ & 0.60295 & 0.07795 & 0.02135 & & & & & & & \\
\hline $\operatorname{ARMA}(4,0)$ & 0.60080 & 0.06671 & -0.06864 & 0.15228 & & & & & & \\
\hline ARMA $(5,0)$ & 0.58985 & 0.07236 & -0.07197 & 0.10985 & 0.07035 & & & & & \\
\hline ARMA $(6,0)$ & 0.58063 & 0.05453 & -0.05759 & 0.10015 & -0.01679 & 0.14551 & & & & \\
\hline $\operatorname{ARMA}(7,0)$ & 0.58787 & 0.05451 & -0.05024 & 0.09341 & -0.01130 & 0.18096 & -0.06163 & & & \\
\hline ARMA $(8,0)$ & 0.58702 & 0.05674 & $\begin{array}{c}-0.05001 \\
\end{array}$ & 0.09497 & -0.01299 & 0.18255 & -0.05265 & $\begin{array}{c}-0.01534 \\
\end{array}$ & & \\
\hline $\operatorname{ARMA}(9,0)$ & 0.58727 & 0.05783 & $\begin{array}{l}-0.05312 \\
\end{array}$ & 0.09458 & -0.01517 & 0.18504 & -0.05505 & -0.02823 & 0.02195 & \\
\hline ARMA $(10,0)$ & 0.58604 & 0.05918 & $\begin{array}{l}-0.04949 \\
\end{array}$ & 0.08478 & -0.01712 & 0.17845 & -0.04629 & -0.03598 & -0.01817 & 0.06831 \\
\hline ARMA $(1,1)$ & 0.75312 & & & & & & & & & \\
\hline $\operatorname{ARMA}(2,1)$ & 1.39970 & -0.43496 & & & & & & & & \\
\hline $\operatorname{ARMA}(3,1)$ & -0.05225 & 0.52430 & 0.00826 & & & & & & & \\
\hline $\operatorname{ARMA}(4,1)$ & 1.24323 & -0.31924 & -0.11346 & 0.12318 & & & & & & \\
\hline $\operatorname{ARMA}(5,1)$ & 1.33450 & -0.37355 & -0.12367 & 0.15158 & -0.03725 & & & & & \\
\hline $\operatorname{ARMA}(6,1)$ & 0.28522 & 0.22950 & -0.03610 & 0.07931 & 0.01672 & 0.16687 & & & & \\
\hline $\operatorname{ARMA}(7,1)$ & 0.74461 & -0.03680 & -0.05859 & 0.10082 & $\begin{array}{l}-0.02648 \\
\end{array}$ & 0.18399 & -0.08480 & & & \\
\hline $\operatorname{ARMA}(8,1)$ & -0.20826 & 0.52546 & -0.00582 & 0.05756 & 0.05380 & 0.17932 & 0.10911 & -0.08011 & & \\
\hline ARMA(9,1) & -0.19884 & 0.51957 & $\begin{array}{l}-0.00903 \\
\end{array}$ & 0.05670 & 0.05344 & 0.17970 & 0.09762 & -0.07628 & 0.01668 & \\
\hline $\operatorname{ARMA}(10,1)$ & 0.56699 & 0.07040 & -0.04841 & 0.08390 & -0.01537 & 0.17811 & -0.04268 & -0.03706 & -0.01876 & 0.06879 \\
\hline $\operatorname{ARMA}(10,2)$ & -0.26579 & -0.29836 & 0.50422 & 0.09413 & 0.02310 & 0.25209 & 0.10769 & 0.09484 & $\begin{array}{l}-0.09784 \\
\end{array}$ & 0.05943 \\
\hline $\operatorname{ARMA}(10,3)$ & 0.51149 & -0.07838 & 0.78081 & -0.33277 & -0.05451 & 0.24153 & -0.11466 & $\begin{array}{l}-0.01912 \\
\end{array}$ & -0.17039 & 0.13406 \\
\hline $\operatorname{ARMA}(10,4)$ & 0.38327 & 0.00193 & 0.77221 & -0.22377 & -0.10340 & 0.23160 & -0.08697 & -0.02519 & -0.17577 & 0.11709 \\
\hline $\operatorname{ARMA}(10,5)$ & -1.13146 & -0.06556 & 0.95650 & 0.77413 & 0.07620 & -0.10191 & 0.33892 & 0.13060 & -0.20583 & -0.18946 \\
\hline $\operatorname{ARMA}(1,2)$ & 0.88700 & & & & & & & & & \\
\hline ARMA(1,3) & 0.93403 & & & & & & & & & \\
\hline ARMA $(1,4)$ & 0.93193 & & & & & & & & & \\
\hline $\operatorname{ARMA}(1,5)$ & 0.93484 & & & & & & & & & \\
\hline $\operatorname{ARMA}(2,2)$ & -0.02219 & 0.53793 & & & & & & & & \\
\hline $\operatorname{ARMA}(2,3)$ & 0.21627 & 0.65017 & & & & & & & & \\
\hline $\operatorname{ARMA}(2,4)$ & 0.19993 & 0.67908 & & & & & & & & \\
\hline
\end{tabular}


Hydrol. Earth Syst. Sci. Discuss., https://doi.org/10.5194/hess-2018-380

Manuscript under review for journal Hydrol. Earth Syst. Sci.

Discussion started: 12 December 2018

(c) Author(s) 2018. CC BY 4.0 License.
Hydrology and

Earth System

Sciences

Discussions (c) (1)

\begin{tabular}{|c|c|c|c|c|c|c|c|c|c|c|}
\hline ARMA $(2,5)$ & 0.23180 & 0.66432 & & & & & & & & \\
\hline $\operatorname{ARMA}(3,2)$ & 0.64304 & 0.68470 & -0.38491 & & & & & & & \\
\hline $\operatorname{ARMA}(3,3)$ & 0.42446 & 0.65453 & -0.16819 & & & & & & & \\
\hline $\operatorname{ARMA}(3,4)$ & -0.21319 & 0.15327 & 0.78757 & & & & & & & \\
\hline $\operatorname{ARMA}(3,5)$ & -0.72403 & 0.74153 & 0.76954 & & & & & & & \\
\hline ARMA $(4,2)$ & 0.69864 & 0.48430 & -0.37004 & 0.11205 & & & & & & \\
\hline ARMA $(4,3)$ & -0.37744 & 1.04098 & 0.50283 & -0.33690 & & & & & & \\
\hline ARMA $(4,4)$ & -0.42158 & 1.00669 & 0.53456 & -0.29754 & & & & & & \\
\hline ARMA(4,5) & 0.49824 & -0.28955 & 0.00477 & 0.62246 & & & & & & \\
\hline $\operatorname{ARMA}(5,2)$ & -0.50475 & -0.14324 & 0.64171 & 0.13615 & 0.05173 & & & & & \\
\hline $\operatorname{ARMA}(5,3)$ & -0.39712 & -0.33977 & 0.55777 & 0.19782 & -0.01648 & & & & & \\
\hline ARMA $(5,4)$ & -0.66573 & 0.97770 & 0.86047 & -0.19813 & -0.14756 & & & & & \\
\hline $\operatorname{ARMA}(5,5)$ & $\begin{array}{l}-0.17019 \\
\end{array}$ & 0.61541 & -0.04977 & -0.06419 & 0.40870 & & & & & \\
\hline ARMA(6,2) & 0.35887 & -0.35880 & 0.29042 & 0.13706 & -0.04217 & 0.24540 & & & & \\
\hline ARMA $(6,3)$ & 0.42395 & -0.24326 & 0.70088 & -0.18135 & -0.08643 & 0.20389 & & & & \\
\hline ARMA $(6,4)$ & 0.39509 & -0.20829 & 0.69730 & -0.14510 & -0.11156 & 0.19805 & & & & \\
\hline ARMA(6,5) & 0.08679 & 0.26106 & -0.29711 & 0.48029 & 0.60613 & -0.29824 & & & & \\
\hline $\operatorname{ARMA}(7,2)$ & -0.17285 & -0.32911 & 0.46577 & 0.11014 & 0.03296 & 0.19965 & 0.14650 & & & \\
\hline $\operatorname{ARMA}(7,3)$ & -0.00080 & -0.29558 & 0.54497 & 0.01053 & 0.00388 & 0.20120 & 0.12022 & & & \\
\hline $\operatorname{ARMA}(7,4)$ & 1.36622 & -0.64456 & 0.93643 & -0.80636 & 0.06862 & 0.28351 & -0.21098 & & & \\
\hline ARMA(7,5) & 0.07913 & 0.23442 & -0.31250 & 0.48226 & 0.60847 & -0.29135 & 0.02455 & & & \\
\hline ARMA $(8,2)$ & -0.06562 & 0.56493 & -0.08504 & 0.05863 & 0.04780 & 0.16703 & 0.08868 & -0.09679 & & \\
\hline ARMA $(8,3)$ & $\begin{array}{l}-0.66504 \\
\end{array}$ & -0.38677 & 0.35814 & 0.33139 & 0.05602 & 0.22303 & 0.23437 & 0.17652 & & \\
\hline $\operatorname{ARMA}(8,4)$ & 0.96323 & -0.34874 & 0.82988 & -0.53430 & 0.01236 & 0.20510 & -0.08258 & $\begin{array}{l}-0.08917 \\
\end{array}$ & & \\
\hline ARMA $(8,5)$ & -1.07677 & -0.28472 & 0.64295 & 0.49656 & 0.08941 & -0.03977 & 0.43053 & 0.33915 & & \\
\hline $\operatorname{ARMA}(9,2)$ & -0.28074 & -0.29950 & 0.52283 & 0.11113 & 0.02688 & 0.25629 & 0.13284 & 0.07980 & -0.11560 & \\
\hline ARMA(9,3) & -0.40831 & -0.32266 & 0.46804 & 0.18178 & 0.04158 & 0.25586 & 0.16121 & 0.10094 & -0.10421 & \\
\hline $\operatorname{ARMA}(9,4)$ & -0.62826 & 0.98023 & 0.80696 & -0.29996 & -0.08852 & 0.21088 & 0.05200 & -0.13123 & -0.07542 & \\
\hline ARMA $(9,5)$ & -1.1315 & 0.65017 & 0.78081 & 0.48226 & -0.11156 & 0.28351 & 0.08868 & -0.08917 & -0.1758 & \\
\hline
\end{tabular}

404 
Hydrol. Earth Syst. Sci. Discuss., https://doi.org/10.5194/hess-2018-380

Manuscript under review for journal Hydrol. Earth Syst. Sci.

Discussion started: 12 December 2018

(C) Author(s) 2018. CC BY 4.0 License.
Hydrology and Earth System Sciences Discussions (c) (1)

Table 8: Showing only MA parameter and constant for ARMA model.

\begin{tabular}{|c|c|c|c|c|c|c|}
\hline & & & MA & eters & & Constant \\
\hline MODELS & $\theta 1$ & $\theta 2$ & $\theta 3$ & $\theta 4$ & $\theta 5$ & \\
\hline $\operatorname{ARMA}(1,0)$ & & & & & & -0.00051 \\
\hline $\operatorname{ARMA}(2,0)$ & & & & & & -0.00129 \\
\hline $\operatorname{ARMA}(3,0)$ & & & & & & -0.00139 \\
\hline $\operatorname{ARMA}(4,0)$ & & & & & & -0.00351 \\
\hline $\operatorname{ARMA}(5,0)$ & & & & & & -0.00456 \\
\hline $\operatorname{ARMA}(6,0)$ & & & & & & -0.00525 \\
\hline $\operatorname{ARMA}(7,0)$ & & & & & & -0.00497 \\
\hline $\operatorname{ARMA}(8,0)$ & & & & & & -0.00477 \\
\hline $\operatorname{ARMA}(9,0)$ & & & & & & -0.00501 \\
\hline $\operatorname{ARMA}(10,0)$ & & & & & & -0.00559 \\
\hline $\operatorname{ARMA}(1,1)$ & -0.16221 & & & & & -0.00215 \\
\hline $\operatorname{ARMA}(2,1)$ & -0.82815 & & & & & -0.00338 \\
\hline $\operatorname{ARMA}(3,1)$ & 0.66709 & & & & & 0.00311 \\
\hline $\operatorname{ARMA}(4,1)$ & -0.66822 & & & & & -0.00463 \\
\hline $\operatorname{ARMA}(5,1)$ & -0.75677 & & & & & -0.00408 \\
\hline $\operatorname{ARMA}(6,1)$ & 0.30166 & & & & & -0.00591 \\
\hline $\operatorname{ARMA}(7,1)$ & -0.15794 & & & & & -0.00470 \\
\hline $\operatorname{ARMA}(8,1)$ & 0.79691 & & & & & -0.00455 \\
\hline $\operatorname{ARMA}(9,1)$ & 0.78870 & & & & & -0.00475 \\
\hline $\operatorname{ARMA}(10,1)$ & 0.01917 & & & & & -0.00562 \\
\hline
\end{tabular}


Hydrol. Earth Syst. Sci. Discuss., https://doi.org/10.5194/hess-2018-380

Manuscript under review for journal Hydrol. Earth Syst. Sci.

Discussion started: 12 December 2018

(C) Author(s) 2018. CC BY 4.0 License.
Hydrology and Earth System Sciences Discussions

\begin{tabular}{|c|c|c|c|c|c|c|}
\hline $\operatorname{ARMA}(10,2)$ & 0.87471 & 0.90483 & & & & 0.00162 \\
\hline $\operatorname{ARMA}(10,3)$ & 0.19815 & -0.77084 & 0.45834 & & & -0.01064 \\
\hline $\operatorname{ARMA}(10,4)$ & 0.21564 & 0.19305 & -0.75702 & -0.11842 & & -0.01140 \\
\hline $\operatorname{ARMA}(10,5)$ & 1.78713 & 1.23513 & -0.25609 & -1.00000 & -0.67359 & -0.03063 \\
\hline $\operatorname{ARMA}(1,2)$ & -0.33688 & -0.16404 & & & & -0.00522 \\
\hline ARMA(1,3) & -0.35536 & -0.15329 & -0.15629 & & & -0.00608 \\
\hline $\operatorname{ARMA}(1,4)$ & -0.35436 & -0.15683 & -0.15869 & 0.01476 & & -0.00611 \\
\hline $\operatorname{ARMA}(1,5)$ & -0.35372 & -0.15800 & -0.15768 & 0.01995 & -0.02017 & -0.00608 \\
\hline $\operatorname{ARMA}(2,2)$ & 0.62654 & -0.03828 & & & & 0.00221 \\
\hline $\operatorname{ARMA}(2,3)$ & 0.35863 & -0.42746 & -0.26765 & & & -0.01054 \\
\hline $\operatorname{ARMA}(2,4)$ & 0.37873 & -0.42551 & -0.28864 & -0.05125 & & -0.01094 \\
\hline $\operatorname{ARMA}(2,5)$ & 0.36628 & -0.40484 & -0.26811 & -0.07566 & -0.09411 & -0.01076 \\
\hline $\operatorname{ARMA}(3,2)$ & -0.09104 & -0.63486 & & & & -0.00590 \\
\hline $\operatorname{ARMA}(3,3)$ & 0.15828 & -0.52132 & -0.18806 & & & -0.00865 \\
\hline $\operatorname{ARMA}(3,4)$ & 0.77956 & 0.30867 & -0.57369 & -0.18270 & & -0.01575 \\
\hline $\operatorname{ARMA}(3,5)$ & 1.35415 & 0.09708 & -0.76904 & -0.36178 & -0.14700 & -0.01603 \\
\hline $\operatorname{ARMA}(4,2)$ & -0.11722 & -0.50226 & & & & -0.00684 \\
\hline $\operatorname{ARMA}(4,3)$ & 1.01092 & -0.42902 & -0.79243 & & & -0.01703 \\
\hline $\operatorname{ARMA}(4,4)$ & 1.06432 & -0.37089 & -0.81084 & -0.04031 & & -0.01738 \\
\hline ARMA $(4,5)$ & 0.08596 & 0.39643 & 0.17633 & -0.41673 & -0.30529 & -0.00931 \\
\hline $\operatorname{ARMA}(5,2)$ & 1.12739 & 0.92096 & & & & 0.01845 \\
\hline $\operatorname{ARMA}(5,3)$ & 1.02365 & 1.06681 & 0.12434 & & & 0.01720 \\
\hline $\operatorname{ARMA}(5,4)$ & 1.31475 & -0.15571 & -1.00000 & -0.28767 & & -0.01530 \\
\hline
\end{tabular}


Hydrol. Earth Syst. Sci. Discuss., https://doi.org/10.5194/hess-2018-380

Manuscript under review for journal Hydrol. Earth Syst. Sci.

Discussion started: 12 December 2018

(C) Author(s) 2018. CC BY 4.0 License.
Hydrology and

Earth System

Sciences

Discussions

\begin{tabular}{|c|c|c|c|c|c|c|}
\hline $\operatorname{ARMA}(5,5)$ & 0.78848 & -0.10724 & -0.07385 & 0.08787 & -0.31487 & -0.01845 \\
\hline ARMA(6,2) & 0.23672 & 0.56680 & & & & 0.00669 \\
\hline $\operatorname{ARMA}(6,3)$ & 0.16843 & 0.41609 & -0.56455 & & & -0.00732 \\
\hline $\operatorname{ARMA}(6,4)$ & 0.19811 & 0.39653 & -0.57059 & -0.04465 & & -0.00843 \\
\hline ARMA(6,5) & 0.54966 & 0.11588 & 0.33089 & -0.21262 & -0.80621 & -0.01506 \\
\hline $\operatorname{ARMA}(7,2)$ & 0.77331 & 0.87867 & & & & 0.00266 \\
\hline $\operatorname{ARMA}(7,3)$ & 0.59455 & 0.73423 & -0.18396 & & & -0.00062 \\
\hline $\operatorname{ARMA}(7,4)$ & -0.78780 & 0.25034 & -0.96854 & 0.50600 & & -0.00029 \\
\hline ARMA(7,5) & 0.56501 & 0.13511 & 0.35062 & -0.18961 & -0.79343 & -0.01516 \\
\hline $\operatorname{ARMA}(8,2)$ & 0.65268 & -0.12361 & & & & -0.00555 \\
\hline $\operatorname{ARMA}(8,3)$ & 1.26941 & 1.23172 & 0.38231 & & & 0.02268 \\
\hline $\operatorname{ARMA}(8,4)$ & -0.37589 & 0.20412 & -0.86433 & 0.21865 & & -0.00413 \\
\hline $\operatorname{ARMA}(8,5)$ & 1.78003 & 1.50000 & 0.18756 & -0.54292 & -0.54283 & 0.04868 \\
\hline ARMA(9,2) & 0.88633 & 0.91781 & & & & 0.00390 \\
\hline ARMA(9,3) & 1.01837 & 1.02326 & 0.13147 & & & 0.01121 \\
\hline $\operatorname{ARMA}(9,4)$ & 1.28045 & -0.18837 & -1.00000 & -0.27298 & & -0.01673 \\
\hline $\operatorname{ARMA}(9,5)$ & 1.35415 & -0.1533 & -0.757 & -0.3618 & -0.67359 & -0.011398 \\
\hline
\end{tabular}

407

\subsection{Maximum likelihood rule}

409 A likelihood value for every of the candidate models (table 9)is calculated which model

410 represents highest likelihood value is chosen for data generation. Gaussian process, general

411 expression of log-likelihood function for the $\mathrm{i}^{\text {th }}$ model is given below.

$412 \quad L_{i}=\ln \left(p\left[z, \widehat{\varphi}_{l}\right]\right)-n_{i}$ 
Hydrol. Earth Syst. Sci. Discuss., https://doi.org/10.5194/hess-2018-380

Manuscript under review for journal Hydrol. Earth Syst. Sci.

Discussion started: 12 December 2018

(C) Author(s) 2018. CC BY 4.0 License.

415 Where, $\mathrm{Li}$ is the likelihood value, $\mathrm{z}$ represents a vector of historical series i.e. parameter vector,

416 MA and parameters $\left(\theta_{1}, \theta_{2}\right.$ $\left.; \varphi_{1}, \varphi_{2}, \ldots \ldots ; \sigma_{i}\right), \sigma_{i}$ represents the residual variance and $n_{i}$ is the number of parameters. As the number of parameters increase, the likelihood value decreases.

Table 9: Showing MLE values constant for ARMA model.

\begin{tabular}{|l|c|l|l|l|c|}
\hline Models & MLE Values & Models & MLE Values & Models & MLE Values \\
\hline ARMA(1,0) & 6.473 & ARMA(10,2) & -14.515 & ARMA(5,2) & -16.810 \\
\hline ARMA(2,0) & 53.207 & ARMA(10,3) & -15.273 & ARMA(5,3) & -29.974 \\
\hline ARMA(3,0) & 4.812 & ARMA(10,4) & -17.592 & ARMA(5,4) & -37.916 \\
\hline ARMA(4,0) & 4.546 & ARMA(10,5) & -51.252 & ARMA(5,5) & -13.428 \\
\hline ARMA(5,0) & 3.268 & ARMA(1,2) & 5.395 & ARMA(6,2) & -39.489 \\
\hline ARMA(6,0) & 0.671 & ARMA(1,3) & 2.531 & ARMA(6,3) & -9.516 \\
\hline ARMA(7,0) & -0.729 & ARMA(1,4) & 1.738 & ARMA(6,4) & -9.926 \\
\hline ARMA(8,0) & -1.772 & ARMA(1,5) & 0.438 & ARMA(6,5) & -18.510 \\
\hline ARMA(9,0) & -2.787 & ARMA(2,2) & 2.875 & ARMA(7,2) & -22.491 \\
\hline ARMA(10,0) & -2.796 & ARMA(2,3) & -7.629 & ARMA(7,3) & -17.672 \\
\hline ARMA(1,1) & 6.031 & ARMA(2,4) & -7.240 & ARMA(7,4) & -20.179 \\
\hline ARMA(2,1) & 1.747 & ARMA(2,5) & -12.101 & ARMA(7,5) & -18.904 \\
\hline ARMA(3,1) & -30.943 & ARMA(3,2) & -7.923 & ARMA(8,2) & -17.325 \\
\hline ARMA(4,1) & 1.620 & ARMA(3,3) & -8.838 & ARMA(8,3) & -26.489 \\
\hline ARMA(5,1) & 0.698 & ARMA(3,4) & -9.603 & ARMA(8,4) & -13.709 \\
\hline
\end{tabular}




\begin{tabular}{|l|c|l|l|l|c|}
\hline ARMA(6,1) & -0.723 & ARMA(3,5) & -43.814 & ARMA(8,5) & -39.369 \\
\hline ARMA(7,1) & -1.542 & ARMA(4,2) & -5.464 & ARMA(9,2) & -26.378 \\
\hline ARMA(8,1) & -4.142 & ARMA(4,3) & -29.525 & ARMA(9,3) & -26.855 \\
\hline ARMA(9,1) & -5.747 & ARMA(4,4) & -30.252 & ARMA(9,4) & -44.180 \\
\hline ARMA(10,1) & -4.396 & ARMA(4,5) & -6.041 & ARMA(9,5) & -37.972 \\
\hline
\end{tabular}

\section{Model Validation}

421 In the present study $\operatorname{ARMA}(2,0)$ (table 9)models has selected as one time step ahead and

422 prediction model by Maximum MLE criteria respectively. The selected model is validate to

423 examine whether the assumptions used for selection of the model are valid.

424

425

426

427

\subsection{Significance of residual mean}

This test examines the validity of the assumption that the error series e $(\mathrm{t})$ has zero mean. A statistic $\eta(e)$ is defined as:

$\mathrm{n}(\mathrm{e})=\frac{N^{1 / 2} \vec{e}}{\rho^{1 / 2}}$

Where, $\overrightarrow{\mathrm{e}}=$ Estimated residual mean.

$\rho=$ Estimated residual variance.

The statistic $\eta(e)$, approximated distribution as $\mathrm{t}(\alpha, \mathrm{N}-1), \alpha$ represents the significance level at test is being carried out. If the value of $\eta(e)<t(\alpha, N-1)$, (table 10) then the mean of the residual series is not significantly different from zero (-)ve series passes the test. 
Hydrol. Earth Syst. Sci. Discuss., https://doi.org/10.5194/hess-2018-380

Manuscript under review for journal Hydrol. Earth Syst. Sci.

Discussion started: 12 December 2018

\begin{tabular}{|c|c|c|c|c|}
\hline $\boldsymbol{\rho}$ & $\boldsymbol{\alpha}$ & $\mathbf{N}$ & $\mathbf{t}(\boldsymbol{\alpha}, \mathbf{N}-\mathbf{1})$ & $\boldsymbol{\eta}(\mathbf{e})$ \\
\hline 0.161472 & .05 & 30 & 1.699 & 0.1 \\
\hline
\end{tabular}

435

436

437 The value of $\eta(\mathrm{e})<\mathrm{t}(\alpha, \mathrm{N}-1)($ i.e. $1.22<1.699)$. It shows that mean of the residual series is not

438 significantly different from zero (-) series passes the test.

439 12. Results and Discussion

440 Outflow data for future are generated by using Frank Copula. The sample size for data

441 generation is taken 100 and 1000. These generated values are compared with observed validation

442 data set. The comparison and the individual dependence of generated samples are also shown in

443 Figure 15, which represents observed data in red color and generated data in blue, data

444 generation by copula with sample size 100 and 1000 of kendall's tau 0.25 and 0.32 , respectively.

445 Figure 16 describes dependence structure for 100 generated samples i.e. Copula is a statistical

446 theory on dependence and measurement of association.

447 
Hydrol. Earth Syst. Sci. Discuss., https://doi.org/10.5194/hess-2018-380

Manuscript under review for journal Hydrol. Earth Syst. Sci.

Discussion started: 12 December 2018

(c) Author(s) 2018. CC BY 4.0 License.
Hydrology and

Earth System

Sciences

Discussions

(c) (1)
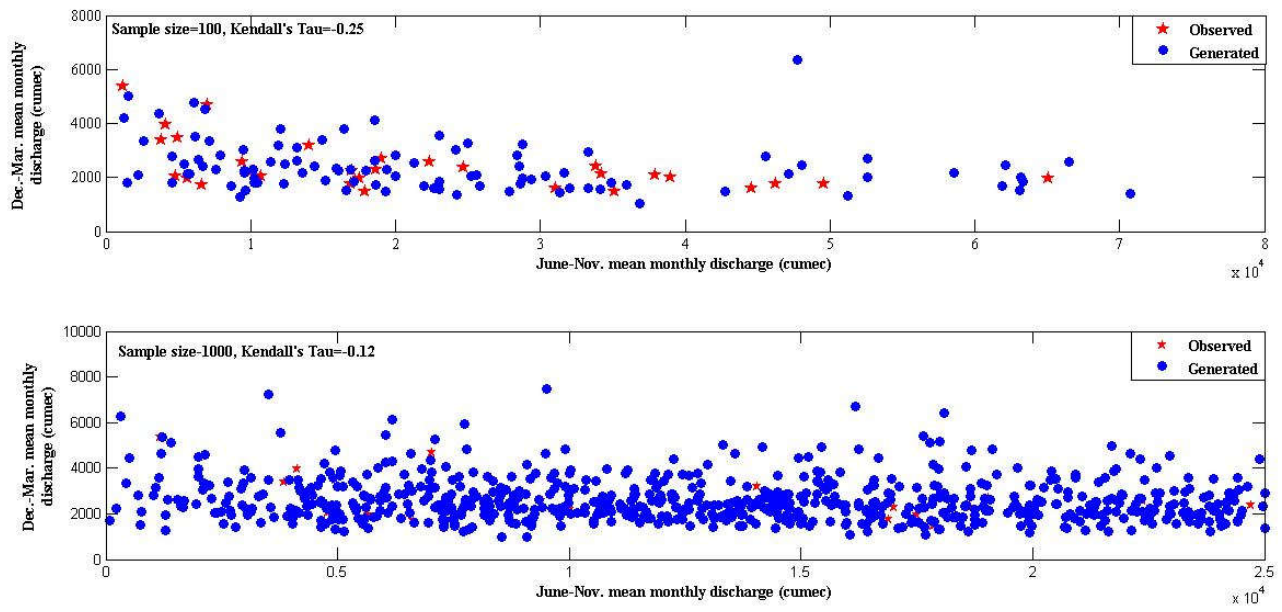

Figure 15. Data generation by Frank Copula.
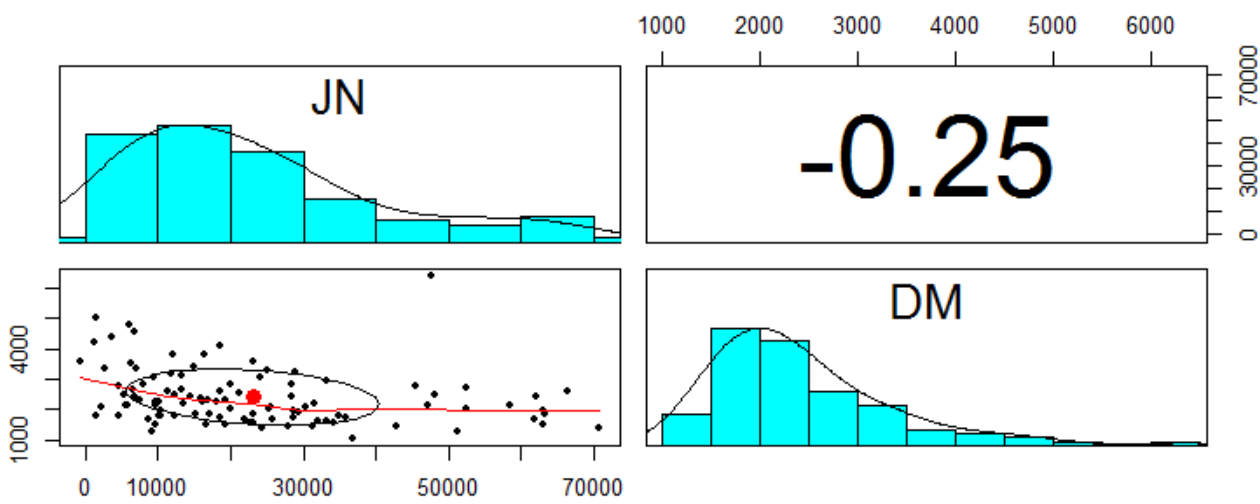

Figure 16. Dependence structure for 100 generated samples. 


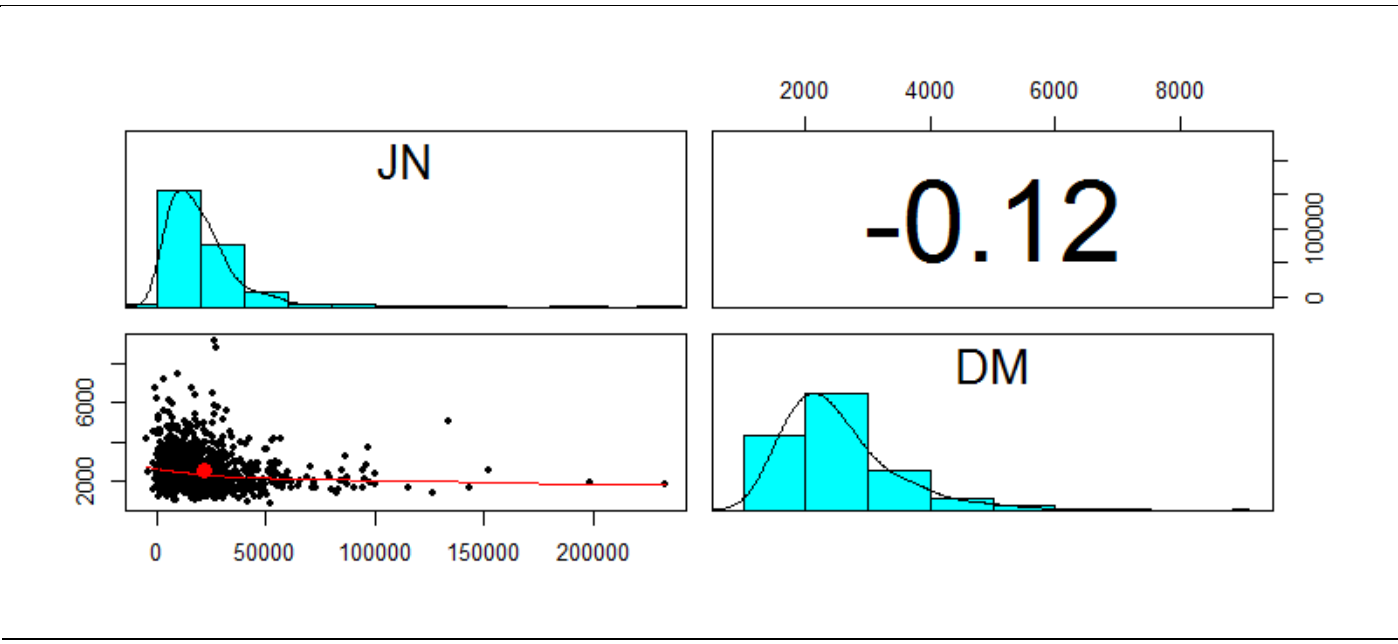

Figure 17. Dependence structure for 1000 generated samples.

Figure 17 describes dependence structure for 1000 generated samples i.e. Copula is a statistical theory on dependence and measurement of association and teal colour shows generated data set month vise. Dependence structure of a multivariate distribution is described by copula, it might be appropriate to use measures of dependence which are copula-based. Linear correlation coefficient can be opposed by the concordance measure spearman's rho and kendall's tau as well as tail dependence and it is expressed by under laying copula.

Figure 20 is a time series of discharge data, blue colour represents observed data from jan. 1968 to dec. 1973 and red colour represents generated data from jan. 1974 to dec. 2004. The green colour shows observed data set and red colour shows generated data set. When generated data set is small, it shows good results because errors incorporated are less in comparison to large data set generation.

In the study area, has analyzed that best model in ARMA $(2,0)$ model, and Frank Copula model for generating discharge data at Farakka barrage on the basis of Mean Square Error (MSE), 
Hydrol. Earth Syst. Sci. Discuss., https://doi.org/10.5194/hess-2018-380

Manuscript under review for journal Hydrol. Earth Syst. Sci.

Discussion started: 12 December 2018

(c) Author(s) 2018. CC BY 4.0 License.

(c) (1)
Hydrology and Earth System

Sciences

Discussions

468 Coefficient of determination $\left(\mathrm{R}^{2}\right)$ (Figure 18 and Figure 19). Based upon all above test Frank

469

Copula is the best model for generating outflow discharge data at Farakka barrage.

470

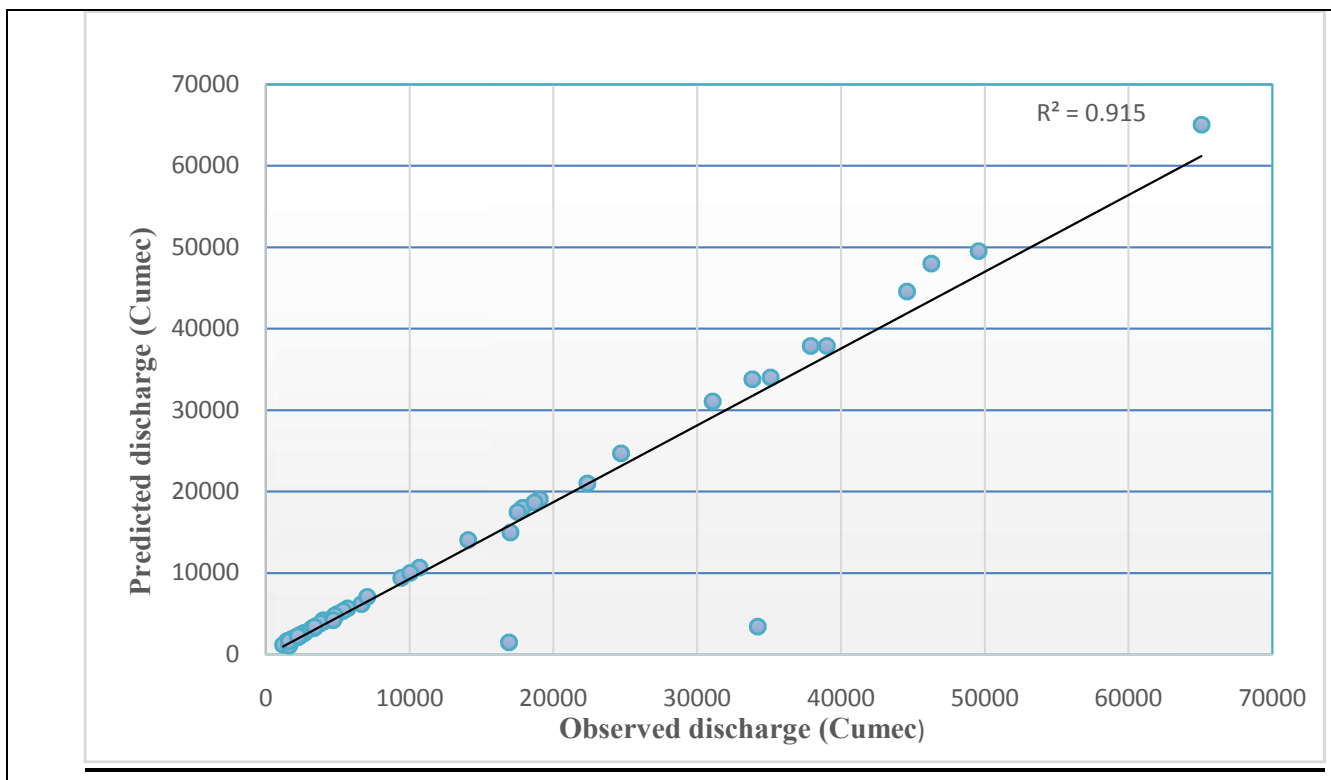

Figure18: Comparison of Observed and predicted data for Frank Copula model.

471 
Hydrol. Earth Syst. Sci. Discuss., https://doi.org/10.5194/hess-2018-380

Manuscript under review for journal Hydrol. Earth Syst. Sci.

(c) Author(s) 2018. CC BY 4.0 License.

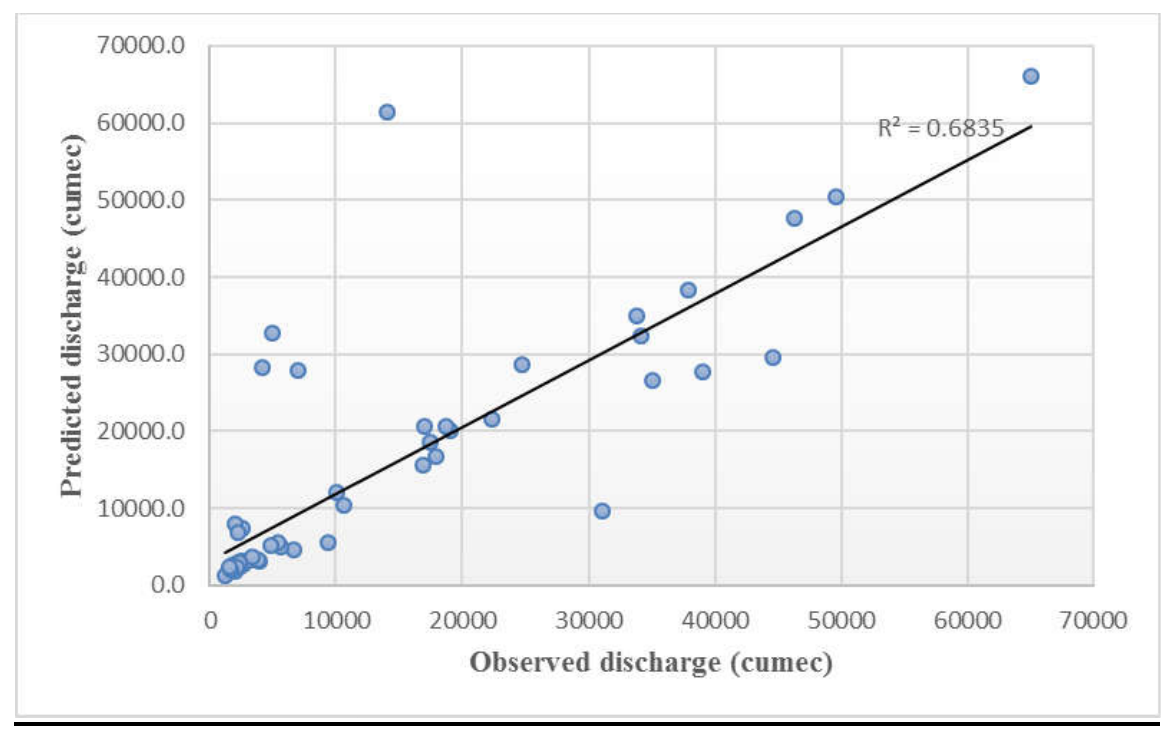

Figure 19 Comparison of Observed and predicted data for $\operatorname{ARIMA}(2,0)$ model.

472

473

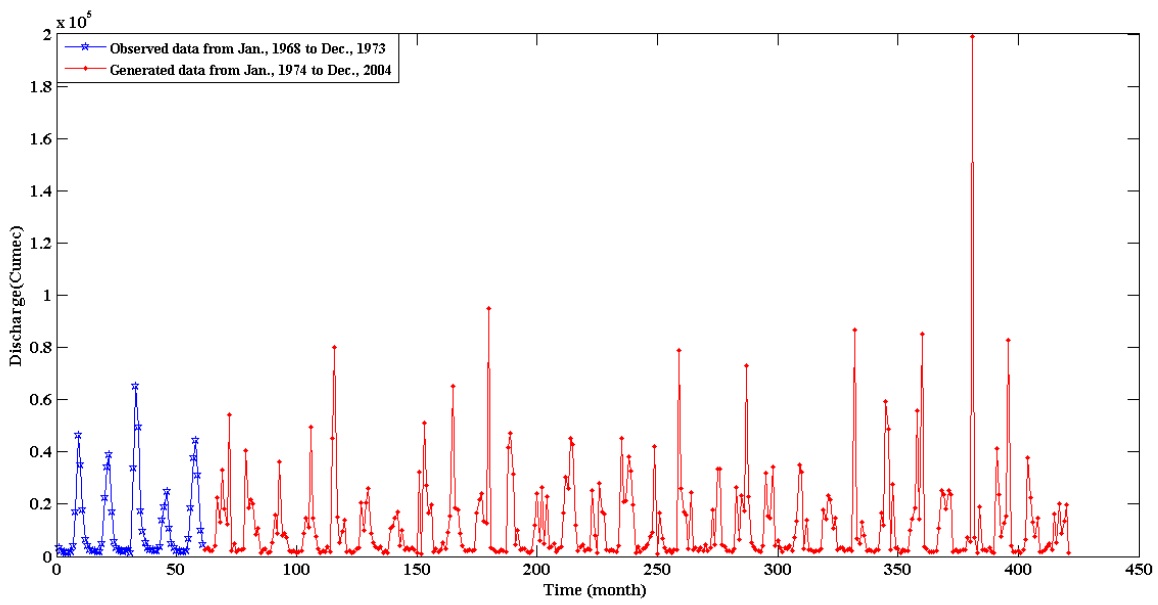

Figure 20. Time series of observed data and generated data. 


\section{Conclusion}

Copula based study and ARMA models are used in this study Frank copula is selected among the copulas based on parameter for discharge data generation and $\operatorname{ARMA}(2,0)$ is selected among the ARMA models. Errors incorporated in the copula model is less in comparison to the $\operatorname{ARMA}(2,0)$ model and the value of Coefficient of determination $\left(\mathrm{R}^{2}\right)$ for Frank is close to one i.e 0.915. Frank copula estimated better result over $\operatorname{ARMA}(2,0)$.

A copula based study which can be used to derive bivariate distribution function of flow rate variables and it shows the real world case study. Best suited model for this study is frank copula among all above copula in term of non parametric tests i.e. AIC, MSE, BIC and KolmogrovSmirnov test. When generated data sample data set, copula shows convergence of sample data set to estimated population. Copula models are an alternative approach and in this study Frank Copula model is used for data generation at Farakka barrage. Bivariate series are prepared based on pre monsoon and post monsoon outflow data. Moreover they are very useful in this study of dependent variable. Copula is very useful for describing the dependence of extreme outcome because it captures the structural dependence of data. The autocorrelation is not captured in the bivariate model .

(1)

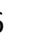

7

(1)




\section{References}

Akaike, H.: A new look at the statistical model identification. IEEE transactions on automatic control, 19(6), 716-723. 1974.

Balistrocchi, M., Orlandini, S., Ranzi, R., \& Bacchi, B.: Copula-Based Modeling of Flood Control Reservoirs, Water Resources Research, 53(11), 9883-9900, 2017.

Chowdhary, H., Escobar, L. A., Singh, V. P.: Identification of suitable copulas for bivariate frequency analysis of flood peak and flood volume data. Hydrology Research, 42(2-3), 193-216, 2011.

De Michele, C., Salvadori, G., Canossi, M., Petaccia, A., \& Rosso, R.: Bivariate statistical approach to check adequacy of dam spillway. Journal of Hydrologic Engineering, 10(1), 50-57, 2005.

Favre, A. C., El Adlouni, S., Perreault, L., Thiémonge, N., \& Bobée, B.: Multivariate hydrological frequency analysis using copulas, Water resources research, 40(1), 2004.

Genest, C., Favre, A. C., Béliveau, J., \& Jacques, C.: Metaelliptical copulas and their use in frequency analysis of multivariate hydrological data. Water Resources Research, 43(9). W09401. DOI:10.1029/2006WR005275, 2007.

Genest, C., Rémillard, B., \& Beaudoin, D.: Goodness-of-fit tests for copulas: A review and a power study. Insurance: Mathematics and economics, 44(2), 199-213. 2009.

Genest, C., \& Rivest, L. P.: Statistical inference procedures for bivariate Archimedean copulas, J of the American statistical Association, 88(423), 1034-1043, 1993.

Ghosh, S.: Modelling bivariate rainfall distribution and generating bivariate correlated rainfall data in neighbouring meteorological subdivisions using copula, Hydrological Processes, 24(24), 3558-3567, 2010. 

Hydraulic Engineering, 124(2), 146-155, 1998.

529 Hooshyaripor, F., Tahershamsi, A., \& Golian, S.: Application of copula method and neural 530 networks for predicting peak outflow from breached embankments. Journal of Hydro531 Environment Research, 8(3), 292-303, 2014.

532 Joe, H.: Multivariate models and multivariate dependence concepts. CRC Press, Chapman and 533 Hall, London, 1997.

534 Kao, S.-C., and Govindaraju, R. S.: Trivariate statistical analysis of extreme rainfall events via 535 Plackett family of copulas, Water Resour. Res., 44(2), W02415, 2008.

536 Kao, S. C., \& Chang, N. B.: Copula-based flood frequency analysis at ungauged basin 537 confluences: Nashville, Tennessee, Journal of Hydrologic Engineering, 17(7), 790-799, 2011.

538 Karmakar, S., and Simonovic, S. P.: "Bivariate flood frequency analysis. Part 2: A copula-based 539 approach with mixed marginal distributions”, J. Flood Risk Manage., 2(1), 32-44,2009.

540 Kashyap, R.: A Bayesian comparison of different classes of dynamic models using empirical 541 data, IEEE Transactions on Automatic Control, 22(5), 715-727,1977.

542 Katz, R. W., \& Skaggs, R. H.: On the use of autoregressive-moving average processes to model 543 meteorological time series, Monthly Weather Review, 109(3), 479-484,1981.

544 Li, T., Guo, S., Chen, L., \& Guo, J.: Bivariate flood frequency analysis with historical 545 information based on copula, Journal of Hydrologic Engineering, 18(8), 1018-1030,2013.

546 Muhaisen, O. S., Osorio, F., \& García, P. A.: Two-copula based simulation for detention basin 547 design,Civil Engineering and Environmental Systems, 26(4), 355-366,2009.

548 Mohan, S., \& Vedula, S.: Multiplicative seasonal ARIMA model for longterm forecasting of 549 inflows, Water resources management, 9(2), 115-126,1995. 
Osorio, F., Muhaisen, O., \& García, P. A.: Copula-based simulation for the estimation of optimal volume for a detention basin, Journal of Hydrologic Engineering, 14(12), 1378-1382,2009.

552 Poulin, A., Huard, D., Favre, A. C., \& Pugin, S.: Importance of tail dependence in bivariate 553 frequency analysis,Journal of Hydrologic Engineering, 12(4), 394-403,2007.

554 Razmkhah, H., AkhoundAli, A. M., Radmanesh, F., \& Saghafian, B.: Evaluation of rainfall spatial correlation effect on rainfall-runoff modeling uncertainty, considering 2-copula,Arabian Journal of Geosciences, 9(4), 323,2016.

Renard, B., \& Lang, M.: Use of a Gaussian copula for multivariate extreme value analysis: some case studies in hydrology, Advances in Water Resources, 30(4), 897-912,2007.

Requena, A. I., Chebana, F., \& Mediero, L.: A complete procedure for multivariate index-flood model application, Journal of Hydrology, 535, 559-580,2016.

Requena, A. I., Flores, I., Mediero, L., \& Garrote, L.:Extension of observed flood series by combining a distributed hydro-meteorological model and a copula-based model, Stochastic environmental research and risk assessment, 30(5), 1363-1378,2016.

Requena AI, Mediero L, Garrote L.: A bivariate return period based on copulas for hydrologic dam design: accounting for reservoir routing in risk estimation, Hydrol Earth Syst Sc 17:3023$3038,2013$.

567 Requena, A. I., Prosdocimi, I., Kjeldsen, T. R., \& Mediero, L.: A bivariate trend analysis to 568 investigate the effect of increasing urbanisation on flood characteristics, Hydrology 569 Research, 48(3), 802-821,2017.

570 Salvadori, G., \& De Michele, C.: On the use of copulas in hydrology: theory and practice, 571 Journal of Hydrologic Engineering, 12(4), 369-380,2007. 
572 Salvadori, G., De Michele, C., Kottegoda, N. T., \& Rosso, R.: Extremes in nature: an approach

573 using copulas (Vol. 56), Springer Science \& Business Media,2007.

574 Shiau, J. T., Feng, S., \& Nadarajah, S.: Assessment of hydrological droughts for the Yellow

575 River, China, using copulas, Hydrological Processes, 21(16), 2157-2163,2007.

576 Sklar A.: Fonction de re'partition a' $\mathrm{n}$ dimensions et leurs marges, vol. 8. Publications de

577 L'Institute de Statistique, Universite' de Paris: Paris; 229-231,1959.

578 Twaróg, B.: An assessment of risks posed by control rule parameters implemented in a flood

579 control reservoir, carried out with the application of elements of ruin theory and of bivariate

580 distribution of a random variable based on the copula function, American Journal of

581 Environmental Engineering, 6(2), 62-71,2016.

582 Vrugt, J. A., Diks, C. G., Gupta, H. V., Bouten, W., \& Verstraten, J. M.: Improved treatment of 583 uncertainty in hydrologic modeling: Combining the strengths of global optimization and data 584 assimilation, Water resources research, 41(1),2005.

585 Wang, Q. J.: A Bayesian joint probability approach for flood record augmentation, Water 586 Resour. Res., 37(6), 1707-1712,2001.

587 Zhang L, Singh V.P.: Trivariate flood frequency analysis using the Gumbel-Hougaard copula, J. 588 Hydrol Eng 12:431-439,2007.

589 Zhang, L. S. V. P., \& Singh, V. P.: Bivariate flood frequency analysis using the copula method, 590 Journal of hydrologic engineering, 11(2), 150-164,2006. 